Article

\title{
Small-sized cuprous oxide species on silica boost acrolein formation via selective oxidation of propylene
}

\author{
Ling-Ling Guo a,h, Jing Yu c, Wei-Wei Wang d, Jia-Xu Liu e,\$, Hong-Chen Guo e, Chao Ma f, ${ }^{\text {, }}$, \\ Chun-Jiang Jia d,\#, Jun-Xiang Chen g, Rui Si a,b,* \\ a Shanghai Institute of Applied Physics, Chinese Academy of Sciences, Shanghai 201800, China \\ b Shanghai Synchrotron Radiation Facility, Zhangjiang Laboratory, Shanghai 201204, China \\ c Shanghai Institute of Measurement and Testing Technology, Shanghai 200233, China \\ d Key Laboratory for Colloid and Interface Chemistry, Ministry of Education, Key Laboratory of Special Aggregated Materials, School of Chemistry and \\ Chemical Engineering, Shandong University, Jinan 250100, Shandong, China \\ e State Key Laboratory of Fine Chemicals, School of Chemical Engineering, Dalian University of Technology, Dalian 116023, Liaoning, China \\ ${ }^{\mathrm{f}}$ College of Materials Science and Engineering, Hunan University, Changsha 410082, Hunan, China \\ g Division of China, TILON Group Technology Limited, Shanghai 200090, China \\ h University of Chinese Academy of Science, Beijing 100049, China
}

\section{A R T I C L E I N F O}

\section{Article history:}

Received 29 March 2020

Accepted 11 May 2020

Published 5 February 2021

\section{Keywords:}

Propylene selective oxidation

Cuprous oxide cluster

Acrolein formation

Active species

In situ characterization

\begin{abstract}
A B S T R A C T
Oxide-supported copper-containing materials have attracted considerable research attention as promising candidates for acrolein formation. Nevertheless, the elucidation of the structure-performance relationships for these systems remains a scientific challenge. In this work, copper oxide clusters deposited on a high-surface-area silica support were synthesized via a deposition-precipitation approach and exhibited remarkable catalytic reactivity (up to $25.5 \%$ conversion and $66.8 \%$ selectivity) in the propylene-selective oxidation of acrolein at $300{ }^{\circ} \mathrm{C}$. Aberration-corrected high-angle annular dark-field scanning transmission electron microscopy combined with X-ray absorption fine structure measurements of the catalyst before and after the reaction confirmed the transformation of the small-sized copper oxide (CuO) clusters into cuprous oxide $\left(\mathrm{Cu}_{2} \mathrm{O}\right)$ clusters. With the aid of in situ X-ray diffraction and in situ dual beam Fourier transform infrared spectroscopy (DB-FTIR), the allyl intermediate $\left(\mathrm{CH}_{2}=\mathrm{CHCH}_{2}{ }^{*}\right)$ was clearly observed, along with the as-formed $\mathrm{Cu}_{2} \mathrm{O}$ species. The intermediate can react with oxygen atoms from neighboring $\mathrm{Cu}_{2} \mathrm{O}$ species to form acrolein during the catalytic process, and the small-sized $\mathrm{Cu}_{2} \mathrm{O}$ clusters play a crucial role in the generation of acrolein via the selective oxidation of propylene.
\end{abstract}

(C) 2021, Dalian Institute of Chemical Physics, Chinese Academy of Sciences. Published by Elsevier B.V. All rights reserved.

\section{Introduction}

Acrolein is one of the most important synthetic intermedi- ates for the production of acrylic acid and methionine in the organic chemical industry [1-3]. Recently, the development of new catalysts for the production of acrolein, including

\footnotetext{
* Corresponding author. Tel: +86-21-33932079; E-mail: sirui@sinap.ac.cn \# Corresponding author. Tel: +86-531-88363683; E-mail: jiacj@sdu.edu.cn

\$Corresponding author. Tel: +86-411-84986162; E-mail: liujiaxu@dlut.edu.cn

${ }^{¥}$ Corresponding author. Tel: +86-731-88821727; E-mail: cma@hnu.edu.cn

This work was supported by the National Natural Science Foundation of China (21773288, 21805167 and 21771117), the National Key Basic Research Program of China (2017YFA0403402), the Excellent Young Scientists Fund from NSFC (21622106), the Outstanding Scholar Fund (grant nos. JQ201703) and the Doctoral Fund (ZR2018BB010) from the Science Foundation of Shandong Province (China), the Taishan Scholar Project of Shandong Province (China), and the Fundamental Research Funds for the Central Universities (China).

DOI: 10.1016/S1872-2067(20)63636-1 | http://www.sciencedirect.com/science/journal/18722067 | Chin. J. Catal., Vol. 42 , No. 2, February 2021
} 
$\mathrm{Bi}_{2} \mathrm{Mo}_{2} \mathrm{O}_{9}$ [4-11], $\mathrm{Ag} / \mathrm{Al}_{2} \mathrm{O}_{3}$ [12], $\mathrm{Cu} / \mathrm{SiO}_{2}$ [13-21], and FeMoTeO [22], has attracted a great deal of research interest. Among them, oxide-supported catalysts containing the non-noble metal copper represent particularly promising candidates with the advantages of high earth-abundance, good thermal stability, and high reactivity for the activation and conversion of propylene to acrolein [21,23-27]. However, major barriers still exist in terms of the elucidation of structure-performance relationships of such copper-based catalysts, and the nature of the active sites in the formation of acrolein remains controversial.

Active copper phases anchored on a silica $\left(\mathrm{SiO}_{2}\right)$ matrix for producing acrolein have been synthesized by "pH-jump" synthesis [21], impregnation [28], microemulsion [29], and sol-gel [30] approaches in aqueous solution. In a previous study, the fresh copper catalyst was determined to consist of a crystalline $\mathrm{CuO}$ phase with a large size of $18 \mathrm{~nm}$, which was converted to a partially reduced $\mathrm{Cu}_{2} \mathrm{O}$ structure after reaction [19], limiting the efficiency of copper toward acrolein formation at low temperatures $\left(<300{ }^{\circ} \mathrm{C}\right)$. Very recently, supported metal or metal oxide clusters prepared via chemical reduction [31,32], deposition precipitation [33], and mass-selected cluster deposition [34] routes have attracted significant attention in heterogeneous catalysis due to their unique features, which include high concentrations of active species, strong metal-support interactions, and unsaturated coordination of the active metal atoms [35-39]. Small-sized (<3 nm) copper or copper oxide clusters of this type are typically obtained using a low copper concentration of approximately $1 \mathrm{wt} \%$ to prevent agglomeration. However, the resulting catalysts exhibited very low conversion in the oxidation of propylene when normalized by the catalyst weight [20]. Thus, methods for the synthesis of small-sized copper or copper oxide catalysts with high $\mathrm{Cu}$ concentrations ( $>5 \mathrm{wt} \%$ ) are still urgently needed.

Additionally, both fully oxidized Cu(II) species [40] and partially reduced $\mathrm{Cu}(\mathrm{I})$ species $[21,41,42]$ have been reported to be more selective in the oxidation of propylene to acrolein. These arguments, as well as the limited exploration of the active sites of copper-based catalysts on the catalyst surface under real working conditions and the structural evolution of the supported metal or metal oxide have impeded significant enhancement in the reactivity of copper-based catalysts for producing acrolein via the selective oxidation of propylene. In situ infrared (IR) spectroscopy is an indispensable technique to detect reaction intermediates for the investigation of reaction mechanisms. However, due to the negative effects of the gas-phase signals of the reactants and/or products, IR studies of the adsorption sites for propylene over copper are usually conducted using carbon monoxide, rather than $\mathrm{C}_{3} \mathrm{H}_{6}$, as the probe molecule $[40,43]$. The in situ dual beam-Fourier transform IR (DB-FTIR) technique can directly monitor the entire reaction process and simultaneously remove the background spectrum of the gas-phase reactants and products under the reaction conditions $[44,45]$. To gain further insight into the non-crystalline structures of ultra-fine metal or metal oxide clusters, the combination of aberration-corrected high-angle annular dark-field scanning transmission electron microscopy
(HAADF-STEM) and X-ray absorption fine structure (XAFS) analysis is highly useful $[46,47]$. Hence, a comprehensive understanding of the catalytically active sites and the reaction mechanism of copper catalysts in the formation of acrolein via the selective oxidation of propylene is urgently needed.

Herein, we report the synthesis of small-sized copper oxide species supported on silica; non-crystalline copper oxide clusters play a key role in governing the catalytic activities of the resulting catalysts. The small-sized copper-silica catalysts were obtained via a deposition-precipitation approach using $\mathrm{Na}_{2} \mathrm{CO}_{3}$ as a precipitating agent and exhibited remarkable reactivity for the oxidation of propylene to acrolein. The best catalyst in our study showed an excellent acrolein formation rate that ranked among those of the most active catalysts for the production of acrolein via the selective oxidation of propylene, and was significantly higher than previously reported values under similar reaction conditions $[20,30,42]$. With the aid of in situ X-ray diffraction (XRD) and in situ DB-FTIR experiments, as well as HAADF-STEM and XAFS measurements, we determined that the small-sized copper species (after $\mathrm{H}_{2}$ reduction at $300{ }^{\circ} \mathrm{C}$ ) were partially oxidized to cuprous oxide $\left(\mathrm{Cu}_{2} \mathrm{O}\right)$ clusters during the propylene oxidation reaction. Additionally, a surface allyl intermediate $\left(\mathrm{CH}_{2}=\mathrm{CHCH}_{2}{ }^{*}\right)$ was clearly observed and reacted with oxygen from neighboring $\mathrm{Cu}_{2} \mathrm{O}$ species on the surface to form acrolein.

\section{Experimental}

\subsection{Catalyst preparation}

\subsubsection{Materials}

All chemicals were of analytical grade and were used without further purification or modification. Silicon dioxide $\left(\mathrm{SiO}_{2}\right.$, $S_{\mathrm{BET}}=688 \mathrm{~m}^{2} / \mathrm{g}, 99.9 \%$ ) was obtained from Evonik Specialty Chemicals (Shanghai) Co., Ltd. Copper nitrate $\left(\mathrm{Cu}\left(\mathrm{NO}_{3}\right)_{2} \cdot 3 \mathrm{H}_{2} \mathrm{O}\right.$, $98.0 \%-102.0 \%)$ and sodium carbonate $\left(\mathrm{Na}_{2} \mathrm{CO}_{3}, 99.8 \%\right)$ were purchased from Sinopharm Chemical Reagent Co., Ltd.

\subsubsection{Preparation of small-sized $\mathrm{Cu} / \mathrm{SiO}_{2}$ samples}

The small-sized $\mathrm{Cu} / \mathrm{SiO}_{2}$ catalysts were prepared by the deposition-precipitation method. Typically, $0.38 \mathrm{~g}$ of $\mathrm{Cu}\left(\mathrm{NO}_{3}\right)_{2} \cdot 3 \mathrm{H}_{2} \mathrm{O}(1.6 \mathrm{mmol})$ and $0.9 \mathrm{~g} \mathrm{SiO} 2$ powder were added to $100 \mathrm{~mL}$ Millipore $\mathrm{H}_{2} \mathrm{O}(>18 \mathrm{M} \Omega \cdot \mathrm{cm})$ under vigorous stirring to synthesize the $10 \mathrm{wt} \% \mathrm{Cu} / \mathrm{SiO}_{2}$ catalyst. Then, an aqueous $\mathrm{Na}_{2} \mathrm{CO}_{3}$ solution $(0.50 \mathrm{M})$ was added to the suspension dropwise until $\mathrm{pH}$ reached $\sim 9$. The blue suspension was further aged at room temperature for $4 \mathrm{~h}$. The as-obtained precipitate was filtered and washed with Millipore water three times. The product was dried in a vacuum at $75^{\circ} \mathrm{C}$ overnight and then calcined in air at $400{ }^{\circ} \mathrm{C}$ for $4 \mathrm{~h}\left(2^{\circ} \mathrm{C} \cdot \mathrm{min}^{-1}\right)$. The synthesized samples are denoted as $x \mathrm{Cu}$-DP $(x=5,10$, and 15), where $x$ is the copper content in weight percent $\left(x=\left[\mathrm{Cu} /\left(\mathrm{Cu}+\mathrm{SiO}_{2}\right)\right] \times\right.$ $100 \%)$.

\subsubsection{Preparation of larger-sized $\mathrm{Cu} / \mathrm{SiO}_{2}$ samples}

For comparison, the incipient wetness impregnation method was used to synthesize larger-sized $\mathrm{Cu} / \mathrm{SiO}_{2}$ catalysts. To 
prepare a $10 \mathrm{wt} \% \mathrm{Cu} / \mathrm{SiO}_{2}$ larger-sized catalyst, $0.38 \mathrm{~g}$ $\mathrm{Cu}\left(\mathrm{NO}_{3}\right)_{2} \cdot 3 \mathrm{H}_{2} \mathrm{O}(1.6 \mathrm{mmol})$ was first dissolved in $2.8 \mathrm{~mL}$ Millipore $\mathrm{H}_{2} \mathrm{O}(>18 \mathrm{M} \Omega \cdot \mathrm{cm})$. The resulting aqueous solution was added dropwise to $0.9 \mathrm{~g} \mathrm{SiO}_{2}$ powder under manual stirring. The powders were allowed to stand under ambient conditions for $2 \mathrm{~h}$, dried at $80^{\circ} \mathrm{C}$ for $12 \mathrm{~h}$, and calcined in air at $400{ }^{\circ} \mathrm{C}$ for 4 $\mathrm{h}\left(2^{\circ} \mathrm{C} \cdot \mathrm{min}^{-1}\right)$. The synthesized samples are denoted as $x \mathrm{Cu}$-IM $(x=5,10$, and 15), where $x$ is the copper content in weight percent $\left(x=\left[\mathrm{Cu} /\left(\mathrm{Cu}+\mathrm{SiO}_{2}\right)\right] \times 100 \%\right)$.

\subsection{Catalyst characterization}

\subsubsection{Transmission electron microscopy}

The HAADF-STEM images were obtained using a JEOL ARM200F microscope equipped with a probe-forming spherical-aberration corrector. The as-calcined catalyst and catalysts that had been used at $300{ }^{\circ} \mathrm{C}$ were tested. Owing to the relatively high atomic number of cations in the $\mathrm{SiO}_{2}$ support, the $\mathrm{Cu}$ contrast in the HAADF images was not clear, particularly in the thick region. To enhance the contrast between $\mathrm{Cu}$ and $\mathrm{Si}$, we set the inner and outer angles of the HAADF detector to 90 and 370 mrad, respectively, and the convergence angle to approximately $30 \mathrm{mrad}$.

\subsubsection{X-ray absorption fine structure}

Ex situ XAFS spectra at the $\mathrm{Cu} K\left(E_{0}=8979 \mathrm{eV}\right)$ edge were obtained at the BL14W1 beamline of the Shanghai Synchrotron Radiation Facility (SSRF), which was operated at $3.5 \mathrm{GeV}$ in "top-up" mode with a constant current of $260 \mathrm{~mA}$. As-calcined and used catalysts were used for characterization. To obtain accurate valence and coordination information for the used copper-silica samples, the samples were transferred to sample tubes as soon as possible and sealed under Ar. For the XAFS tests, approximately $30 \mathrm{mg}$ of powder was pressed into a solid pellet and sealed with Kapton tape. The XAFS data were recorded in transmission mode with a Si(111) monochromator and Oxford ion chambers. The energy was calibrated according to the absorption edge of pure $\mathrm{Cu}$ foil. The programs Athena and Artemis were used to extract the data and fit the profiles. For the X-ray absorption near edge spectroscopy (XANES) part, the experimental absorption coefficients as a function of the energies $\mu(E)$ were processed by background subtraction and normalization procedures and reported as "normalized absorption". Based on the normalized XANES profiles, the oxidation state of copper can be determined by linear combination fitting with the help of bulk references $\left(\mathrm{Cu}\right.$ foil for $\mathrm{Cu}^{0}, \mathrm{Cu}_{2} \mathrm{O}$ for $\mathrm{Cu}^{+}$, and $\mathrm{CuO}$ for $\mathrm{Cu}^{2+}$ ). For the extended X-ray absorption fine structure (EXAFS) part, the Fourier transformed (FT) data in $R$ space were analyzed by applying $\mathrm{Cu}_{2} \mathrm{O}$ and $\mathrm{CuO}$ models for the $\mathrm{Cu}-\mathrm{O}$ and $\mathrm{Cu}-\mathrm{Cu}$ contributions. The parameters describing the electronic properties (e.g., correction of the photoelectron energy origin, $E_{0}$ ) and the local structure environment, including $C N$, distance $(R)$, and the Debye-Waller factor around the absorbing atoms, were allowed to vary during the fitting process. The fitted ranges for the $\mathrm{k}$ and $\mathrm{R}$ spaces were selected as $k=$ 3-12 $\AA^{-1}$ with $\mathrm{R}=0.8-3.8 \AA$ ( $k^{3}$-weighted).

\subsubsection{In situ X-ray diffraction}

In situ XRD was performed using a PANalytical X'pert3 powder diffractometer $(40 \mathrm{kV}, 40 \mathrm{~mA})$ with an Anton Paar XRK-900 reaction chamber in the $2 \theta$ range $10^{\circ}-90^{\circ}$ at a scan rate of $4^{\circ} / \mathrm{min}$. The as-calcined catalysts were used directly as the tested samples. The powder sample $(15 \mathrm{mg})$ was loaded directly into a ceramic sample holder (diameter $=10 \mathrm{~mm}$, depth = $1 \mathrm{~mm}$ ); the mass transfer during this process was non-existent. The instrument was programmed to collect the XRD patterns of the measured sample at $30{ }^{\circ} \mathrm{C}$ initially. The powder was then heated to a series of temperatures $(100,200$, 250,300 , and $350{ }^{\circ} \mathrm{C}$ ) at a constant rate of $10^{\circ} \mathrm{C} / \mathrm{min}$ under a $5 \% \mathrm{H}_{2} / \mathrm{Ar}$ flow $\left(50 \mathrm{~cm}^{3} \cdot \mathrm{min}^{-1}\right)$; each temperature was maintained for $10 \mathrm{~min}$ before the XRD pattern was recorded. To determine the phase transformation of the catalysts during the $\mathrm{C}_{3} \mathrm{H}_{6}$ oxidation reaction, the sample was loaded into a ceramic sample holder, heated to $300{ }^{\circ} \mathrm{C}$ for $30 \mathrm{~min}$ in $5 \% \mathrm{H}_{2} / \mathrm{Ar}$, and cooled to $30^{\circ} \mathrm{C}$; the gas was then changed to high purity Ar for 10 min before the XRD pattern was recorded. Finally, the sample was heated to 250 or $300{ }^{\circ} \mathrm{C}$ for 320 min in $1 \% \mathrm{C}_{3} \mathrm{H}_{6} / \mathrm{Ar}(20$ $\left.\mathrm{cm}^{3} \cdot \mathrm{min}^{-1}\right)$ together with $1 \% \mathrm{O}_{2} / \mathrm{N}_{2}\left(20 \mathrm{~cm}^{3} \cdot \mathrm{min}^{-1}\right)$ with XRD pattern collection.

\subsubsection{In situ dual beam Fourier transform infrared spectroscopy}

In situ DB-FTIR spectrometry was used to study the surface reaction processes and the structure of the adsorbents and intermediates on $\mathrm{SiO}_{2}$ and the catalysts under real reaction conditions. The as-calcined catalysts were used directly as the tested samples. The sample was pressed into self-supporting thin wafers $\left(1 \mathrm{~cm}^{2}\right)$, which were placed in the sample beam, while the reference beam was vacant. Before recording, the sample was first treated with $5 \% \mathrm{H}_{2} / \mathrm{Ar}$ at $300{ }^{\circ} \mathrm{C}$ in the dual beam IR cell reactor for $30 \mathrm{~min}$. The sample was then cooled to $30{ }^{\circ} \mathrm{C}$ and evacuated $\left(10^{-3} \mathrm{pa}\right)$ for $1 \mathrm{~h}$. Pure $\mathrm{N}_{2}\left(90 \mathrm{~mL} \cdot \mathrm{min}^{-1}\right)$ was passed through the reactor for $10 \mathrm{~min}$ as the temperature was increased from $30{ }^{\circ} \mathrm{C}$ to $300{ }^{\circ} \mathrm{C}$. Ten minutes later, recording of spectra was started; the spectra were acquired with a resolution of $4 \mathrm{~cm}^{-1}$ and 64 scans in the region 3350-1350 $\mathrm{cm}^{-1}$, and an additional gas feed of $\mathrm{C}_{3} \mathrm{H}_{6}\left(2.5 \mathrm{~mL} \cdot \mathrm{min}^{-1}\right)$ was introduced to the system. After $30 \mathrm{~min}$, the same amount of $\mathrm{O}_{2}$ (2.5 $\mathrm{mL} \cdot \mathrm{min}^{-1}$ ) was added, and the gas composition was maintained as $\mathrm{C}_{3} \mathrm{H}_{6} / \mathrm{O}_{2} / \mathrm{N}_{2}\left(2.5 / 2.5 / 90,95 \mathrm{~mL} \cdot \mathrm{min}^{-1}, 1 \mathrm{~atm}\right)$ for 90 $\min$. The spectra were obtained by subtracting the background spectrum (obtained from the sample-free reference beam) from the measured sample spectra.

\subsection{5. $\mathrm{N}_{2} \mathrm{O}$ chemisorption}

$\mathrm{N}_{2} \mathrm{O}$ chemisorption was carried out in a Builder PCSA-1000 instrument loaded with the sieved catalyst (20-40 mesh, 50 $\mathrm{mg}$ ) to determine the $\mathrm{Cu}$ dispersion. First, the as-calcined samples were subjected to the $\mathrm{H}_{2}$-TPR procedure as described in supporting information until $500{ }^{\circ} \mathrm{C}$. The amount of $\mathrm{H}_{2}$ consumption (A1) measured by the thermal conductivity detector (TCD) in this step corresponded to the total amount of $\mathrm{CuO}$. The catalyst bed was then cooled to $35{ }^{\circ} \mathrm{C}$ and flushed with helium $\left(30 \mathrm{~mL} \cdot \mathrm{min}^{-1}\right)$ for $1 \mathrm{~h}$. The metallic copper atoms at the surface 
were selectively oxidized in a $20 \% \mathrm{~N}_{2} \mathrm{O} / \mathrm{N}_{2}$ gas mixture $(30$ $\mathrm{mL} \cdot \mathrm{min}^{-1}$ ) at $35{ }^{\circ} \mathrm{C}$ for $1 \mathrm{~h}$. Finally, the samples were again flushed with $\mathrm{He}$ for $1 \mathrm{~h}$ and subjected to another $\mathrm{H}_{2}$-TPR run to a maximum temperature of $500{ }^{\circ} \mathrm{C}$. The amount of $\mathrm{H}_{2}$ consumption (A2) during this run corresponded to the amount of surface $\mathrm{Cu}_{2} \mathrm{O}$. Thus, the $\mathrm{Cu}$ dispersion was derived as $D=$ $2 \mathrm{~A} 2 / \mathrm{A} 1 \times 100 \%$.

\subsection{Catalytic tests}

The catalytic tests were carried out in a fixed bed reactor using $100 \mathrm{mg}$ of sieved (40-60 mesh) powder in a gas mixture consisting of $\mathrm{C}_{3} \mathrm{H}_{6}\left(2.5 \mathrm{~cm}^{3} \cdot \mathrm{min}^{-1}\right), \mathrm{O}_{2}\left(2.5 \mathrm{~cm}^{3} \cdot \mathrm{min}^{-1}\right)$, and $10 \%$ $\mathrm{N}_{2} / \mathrm{Ar}\left(45 \mathrm{~cm}^{3} \cdot \mathrm{min}^{-1}\right)$ (from Jinan Deyang Corporation) at a total flow rate of $50 \mathrm{~cm}^{3} \cdot \mathrm{min}^{-1}$, corresponding to a space velocity of $30000 \mathrm{~cm}^{3} \cdot \mathrm{h}^{-1} \cdot \mathrm{g}_{\mathrm{cat}}{ }^{-1}$. Before the reaction, the catalysts were pretreated in $75 \% \mathrm{H}_{2} / \mathrm{Ar}\left(30 \mathrm{~cm}^{3} \cdot \mathrm{min}^{-1}\right)$ at $300{ }^{\circ} \mathrm{C}$ for 30 min for activation. After the catalysts had cooled to room temperature, $10 \% \mathrm{~N}_{2} / \mathrm{Ar}$ was passed through the reactor for 10 min. Subsequently, the gas mixture was switched to the reaction gas, the reactor was heated to temperatures from 225 to $325{ }^{\circ} \mathrm{C}$ (interval: $25^{\circ} \mathrm{C}$ ) for the "light off" tests, and data was collected for a time on stream of $7 \mathrm{~h}$. The products and reactants in the gas phase were detected online using a Shimadzu gas chromatograph (GC-9160). $\mathrm{CO}_{2}, \mathrm{C}_{3} \mathrm{H}_{6}$, and $\mathrm{N}_{2}$ were analyzed using a column packed with Porapak $\mathrm{Q}$ and $5 \mathrm{~A}$ molecular sieves and a TCD. Aldehyde, propanal, acetone, $\mathrm{C}_{3} \mathrm{H}_{6}$, propylene oxide, and acrolein were analyzed using an AE-FFAP capillary column with a flame ionization detector (FID). The carbon balance was calculated to be $100 \pm 3 \%$.

The conversion of propylene, the selectivity $\left(S_{x}\right)$, the yield of acrolein and other byproducts, and the formation rate of acrolein ( $r$ acrolein), were defined considering the reaction $a \mathrm{C}_{3} \mathrm{H}_{6} \rightarrow$ $b C_{x}$ as follows:

$$
\begin{gathered}
\text { conversion }(\%)=\frac{\sum \frac{a}{b} n_{x}}{n_{C_{3} H_{6}}^{\text {out }}+\sum \frac{a}{b} n_{x}} \times 100 \\
S_{x}(\%)=\frac{\frac{a}{b} n_{x}}{\sum_{\frac{a}{b} n_{x}}^{a}} \times 100 \\
\text { Yield (\%) = conversion } \times \text { selectivity } \times 100 \\
r_{\text {acrolein }}=\frac{\text { conversion } \times S_{\text {acrolein }} \times n_{C_{3} H_{6}}^{\text {in }}}{m_{\text {Cu }}} \\
r_{\text {acrolein }}=\frac{\text { conversion } \times S_{\text {acrolei } n} \times n_{C_{3} H_{6}}^{\text {in }}}{m_{\text {cat }}}
\end{gathered}
$$

where $n_{x}$ is the partial mole of the products obtained during the oxidation of propylene (aldehyde, propane, acetone, propylene oxide, acrolein, and $\mathrm{CO}_{2}$ ). To measure the reaction rates using Arrhenius plots, the corresponding propylene conversions were tuned within $20 \%$ to exclude mass transfer limitations. Mass and heat transfer calculations were carried out using the catalyst $10 \mathrm{Cu}-\mathrm{DP}$ in this reaction (see supplementary information, Table S1-S4). The Weisz-Prater criterion, $C_{W P}=\frac{-r_{A(b) s)}^{\prime} \rho_{c} R^{2}}{D_{e} C_{A s}}<1$, gave $7.15 \times 10^{-2}<1$, indicating the absence of internal diffusion limitations during our tests $[48,49]$.
The Mears criterion, $\frac{-r_{A}{ }_{A} R^{2}}{C_{A b} D_{e}}<\frac{1+0.33 \gamma \chi}{\left|n-\gamma_{b} \beta_{b}\right|(1+0.33 n \omega)}$, gave $1.78 \times$ $10^{-2}<2$, indicating the absence of interphase and intraparticle heat or mass transport limitations [48]. The above mathematical calculations verified that the mass and heat transfer limitations could be neglected in our measurements.

\section{Results and discussion}

\subsection{Catalyst performance in acrolein formation via selective oxidation of propylene}

The catalytic activities of the $\mathrm{Cu}$ species loaded on the $\mathrm{SiO}_{2}$ support were obtained using a fixed-bed reactor for the direct oxidation of propylene solely by oxygen molecules $\left(5 \% \mathrm{C}_{3} \mathrm{H}_{6} / 5 \% \mathrm{O}_{2} / 9 \% \mathrm{~N}_{2} / 81 \% \mathrm{Ar}\right)$. To activate the measured samples, a hydrogen pretreatment temperature of $300{ }^{\circ} \mathrm{C}$ was used based on the complete $\mathrm{H}_{2}$ consumption of hydrogen at this temperature in the hydrogen temperature-programmed reduction ( $\mathrm{H}_{2}$-TPR) profiles (Fig. $\mathrm{S} 1$ and Table $\mathrm{S} 5$ ). In the experiments, the activities of all the copper-silica catalysts varied with the collection time (Figs. S2-S4), indicating the existence of an induction/deactivation period, possibly due to structural changes at the beginning of the reaction $[18,50]$. Thus, the propylene $\left(\mathrm{C}_{3} \mathrm{H}_{6}\right)$ conversion and selectivity of acrolein and other byproducts $\left(\mathrm{CO}_{2}\right.$, aldehyde, propane, acetone, propylene oxide, etc.) of all the tested catalysts were averaged using data obtained from 160 to $320 \mathrm{~min}$, during which the system was in a relatively steady state.

Table 1 summarizes the propylene conversion, product selectivity, and acrolein formation rate over different catalysts at various reaction temperatures. Noteworthily, acrolein and $\mathrm{CO}_{2}$ were the predominant products. The combined selectivity toward these two products was nearly $85 \%$ at a reaction temperature of $225{ }^{\circ} \mathrm{C}$, and exceeded $95 \%$ when the reaction temperature was raised. Figure 1 (a) shows the $\mathrm{C}_{3} \mathrm{H}_{6}$ conversion and acrolein selectivity for deposition-precipitation-synthesized 10Cu-DP at reaction temperatures of $225-325{ }^{\circ} \mathrm{C}$ (for details, refer to Fig. S2). This sample clearly underwent a "light off" period (rapid increase in both $\mathrm{C}_{3} \mathrm{H}_{6}$ conversion and acrolein selectivity) from 225 to $300{ }^{\circ} \mathrm{C}$, and gave a $\mathrm{C}_{3} \mathrm{H}_{6}$ conversion of $25.5 \%$ and acrolein selectivity of $66.8 \%$ at $300{ }^{\circ} \mathrm{C}$ (Table 1 ). This corresponded to an acrolein yield of $17.0 \%$, which is higher than the results in the literature under similar reaction conditions (Table S6). At $325{ }^{\circ} \mathrm{C}$, the sample gave a higher $\mathrm{C}_{3} \mathrm{H}_{6}$ conversion of $29.5 \%$, while the acrolein selectivity dropped to $61.0 \%$ (Table 1). As shown in Fig. 1(b), the $\mathrm{C}_{3} \mathrm{H}_{6}$ conversion increased almost linearly with the $\mathrm{Cu}$ loading amount from $5 \mathrm{Cu}$ $(13.6 \%)$ to $10 \mathrm{Cu}(25.5 \%)$ and $15 \mathrm{Cu}(32.7 \%)$, while the acrolein selectivity decreased from $5 \mathrm{Cu}(72.8 \%)$ to $10 \mathrm{Cu}(66.8 \%)$ and $15 \mathrm{Cu}(63.3 \%)$ (for details, refer to Fig. S3). Thus, 10Cu-DP, which exhibited both high propylene conversion/acrolein selectivity and good product yield, was selected as a typical sample for activity comparison in this work.

Furthermore, the synthetic strategy also plays crucial role in the high reactivity of our copper-silica catalyst. We prepared copper-silica samples via an incipient wetness impregnation 
Table 1

Catalytic performance of catalysts with different Cu weight percentages and particle sizes in propylene oxidation.

\begin{tabular}{|c|c|c|c|c|c|c|c|c|c|c|c|}
\hline \multirow{2}{*}{ Sample } & \multirow{2}{*}{$\begin{array}{c}T \\
\left({ }^{\circ} \mathrm{C}\right)\end{array}$} & \multirow{2}{*}{$\begin{array}{c}\text { Conversion } \\
(\%)\end{array}$} & \multicolumn{6}{|c|}{ Selectivity (\%) } & \multirow{2}{*}{$\begin{array}{c}r_{\text {acrolein }} \\
\left(\mathrm{mmol}^{-1} \cdot \mathrm{h}_{\mathrm{Cu}}\right) \\
\end{array}$} & \multirow{2}{*}{$\begin{array}{c}r_{\text {acrolein }} \\
\left(\mathrm{mmol} \cdot \mathrm{h}^{-1} \cdot \mathrm{g}_{\mathrm{cat}}\right)\end{array}$} & \multirow{2}{*}{$\begin{array}{l}D_{\mathrm{Cu} 20^{\mathrm{a}}} \\
(\mathrm{nm})\end{array}$} \\
\hline & & & Acrolein & $\mathrm{CO}_{2}$ & $\mathrm{PO}$ & Acetone & Propanal & Aldehyde & & & \\
\hline 5Cu-DP & 300 & 13.6 & 72.8 & 24.5 & 0.9 & 0.4 & 0.2 & 1.2 & 127.1 & 6.1 & 2.6 \\
\hline 10Cu-DP & 225 & 0.7 & 41.6 & 43.1 & 11.8 & 1.3 & 0.5 & 1.7 & 1.9 & 0.2 & 2.5 \\
\hline 10Cu-DP & 250 & 3.4 & 49.6 & 40.9 & 6.7 & 1.0 & 0.3 & 1.5 & 11.1 & 1.0 & 2.5 \\
\hline 10Cu-DP & 275 & 12.7 & 57.9 & 38.8 & 1.6 & 0.2 & 0.2 & 1.3 & 47.9 & 4.5 & 2.7 \\
\hline 10Cu-DP & 300 & 25.5 & 66.8 & 30.7 & 0.4 & 0.1 & 0.1 & 1.9 & 111.2 & 10.5 & 2.8 \\
\hline 10Cu-DP & 325 & 29.5 & 61.0 & 36.5 & 0.2 & 0.1 & 0.1 & 2.1 & 117.4 & 12.7 & 3.1 \\
\hline 15Cu-DP & 300 & 32.7 & 63.3 & 34.2 & 0.2 & 0.1 & 0.1 & 2.1 & 85.3 & 12.7 & 3.5 \\
\hline 5Cu-IM & 300 & 2.5 & 75.5 & 20.8 & 0.7 & 0.3 & 0.5 & 2.2 & 23.2 & 1.2 & 12.8 \\
\hline 10Cu-IM & 300 & 3.8 & 74.7 & 22.0 & 0.4 & 0.6 & 0.4 & 1.9 & 17.2 & 1.7 & 20.3 \\
\hline 15Cu-IM & 300 & 4.3 & 72.5 & 23.9 & 0.8 & 0.5 & 0.4 & 1.9 & 12.8 & 1.9 & 28.3 \\
\hline
\end{tabular}

a Particle size of the samples calculated from the XRD data using the Scherrer equation.

Reaction conditions: 0.10 g catalyst; $\mathrm{C}_{3} \mathrm{H}_{6}: \mathrm{O}_{2}: \mathrm{N}_{2} / \mathrm{Ar}=2.5: 2.5: 45 ; 30000 \mathrm{~cm}^{3} \cdot \mathrm{h}^{-1} \cdot \mathrm{g}_{\mathrm{cat}}{ }^{-1} ; 50 \mathrm{~mL} \cdot \mathrm{min}^{-1}$.

method (Cu-IM) for comparison with the catalyst fabricated using the deposition-precipitation approach. Figure 1(c) shows the catalytic performance of both 10Cu-DP and 10Cu-IM (for details of the other $\mathrm{Cu}$-IM catalysts, refer to Fig. S4) as a function of reaction time in the selective oxidation of propylene at $300{ }^{\circ} \mathrm{C}$. The acrolein selectivity of $10 \mathrm{Cu}$-DP $(\sim 66.8 \%)$ is lower than that of $10 \mathrm{Cu}-\mathrm{IM}(\sim 74.7 \%)$, whereas the propylene conversion of the former is four times higher than that of the latter. This phenomenon indicates the structural dependence of the copper species in the selective oxidation of propylene. The normalized catalytic activity results in Fig. 1(d) show that 10Cu-DP exhibits a significantly higher acrolein formation rate than $10 \mathrm{Cu}-\mathrm{IM}$ on both a catalyst mass and $\mathrm{Cu}$ mass basis.
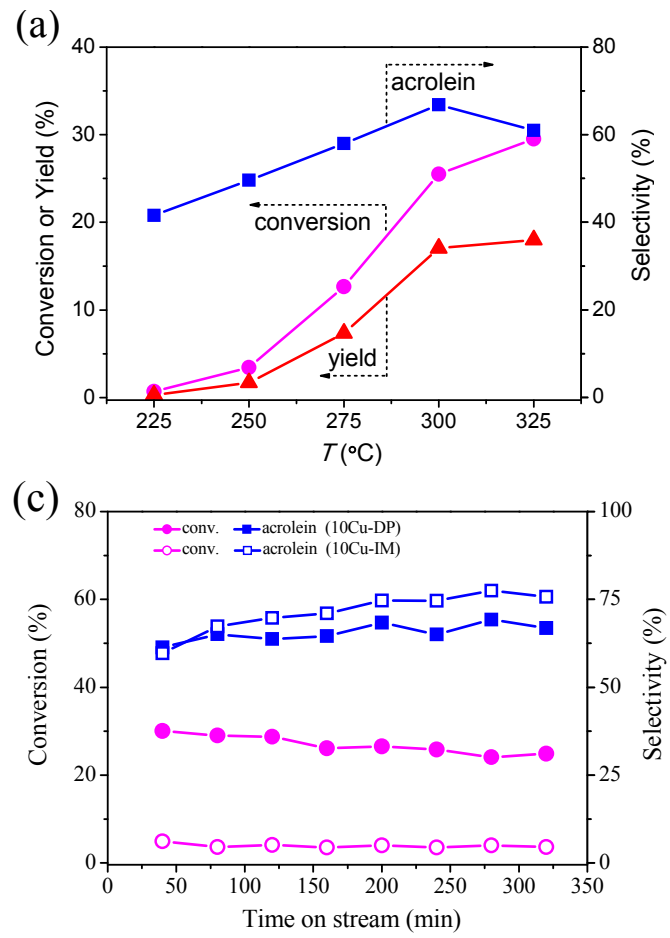

For kinetic studies, the reaction rates of $10 \mathrm{Cu}-\mathrm{DP}$, which was synthesized by the deposition-precipitation approach, and $10 \mathrm{Cu}-\mathrm{IM}$, which was prepared by the incipient wetness impregnation method, were measured at low propylene conversions in the temperature range $250-325^{\circ} \mathrm{C}$. Based on the Arrhenius plots in Fig. S5, the apparent activation energies $\left(E_{\mathrm{a}}\right)$ of $10 \mathrm{Cu}-\mathrm{DP}$ and $10 \mathrm{Cu}-\mathrm{IM}$ were calculated to be $57.9 \pm 5.8 \mathrm{~kJ} \cdot \mathrm{mol}^{-1}$ and $64.0 \pm 4.1 \mathrm{~kJ} \cdot \mathrm{mol}^{-1}$, respectively. These values were close to those previously reported for such copper-based catalysts $[20,29]$. The similar apparent activation energies suggested that the two types of catalysts might catalyze the reaction via the same type of active site, implying that the significant difference in the catalytic behavior of the catalysts could be at-
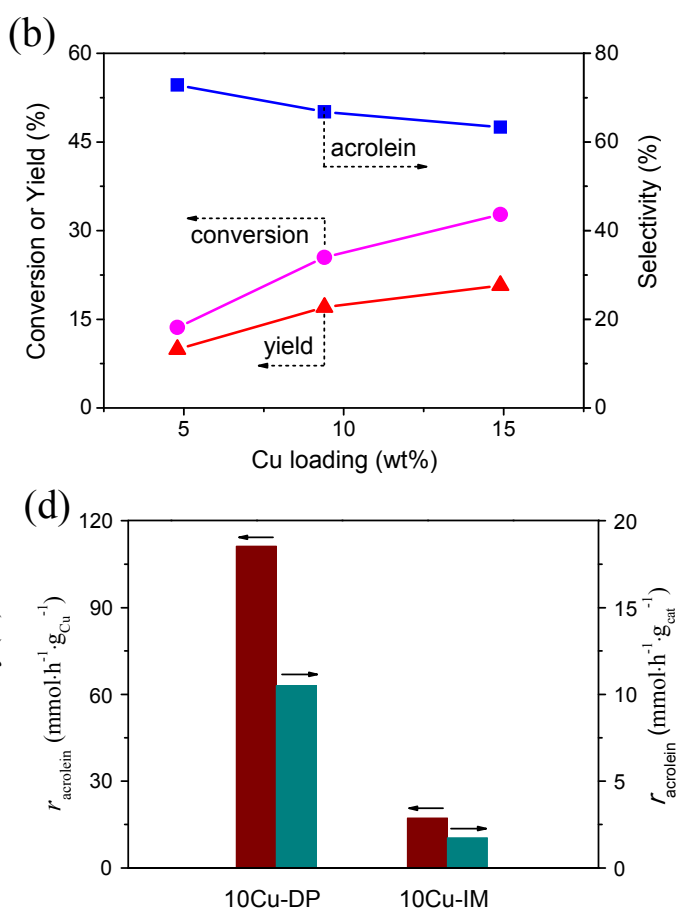

Fig. 1. Catalytic performance of the $\mathrm{Cu} / \mathrm{SiO}_{2}$ catalysts. (a) Temperature dependence of the catalytic activity of $10 \mathrm{Cu}-\mathrm{DP}$ in the range $225-325{ }^{\circ} \mathrm{C}$; (b) $\mathrm{Cu}$-loading dependence of the catalytic activity of the copper-silica catalysts at $300{ }^{\circ} \mathrm{C}$; Comparisons of (c) the propylene conversion and acrolein selectivity with time on stream and (d) the acrolein formation rates of $10 \mathrm{Cu}-\mathrm{DP}$ and $10 \mathrm{Cu}-\mathrm{IM}$ in the selective oxidation of propylene at $300{ }^{\circ} \mathrm{C}$. Reaction conditions: $0.1 \mathrm{~g}$ catalyst, $\mathrm{C}_{3} \mathrm{H}_{6}: \mathrm{O}_{2}: \mathrm{N}_{2} / \mathrm{Ar}=2.5: 2.5: 45,30000 \mathrm{~cm}^{3} \cdot \mathrm{h}^{-1} \cdot \mathrm{g}_{\text {cat }}{ }^{-1}$. 
tributed to an intrinsic difference in the copper species under the reaction conditions. Notably, the Arrhenius formula assumes that the activation energy $\left(E_{\mathrm{a}}\right)$ is a constant and independent of temperature, which was consistent with the experimental results only within a certain temperature range.

As shown in Table 1, the catalytic activity as measured by the acrolein formation rate normalized by the copper mass and catalyst mass of 10Cu-DP increased rapidly with increasing reaction temperature from 225 to $300{ }^{\circ} \mathrm{C}$, indicating that our copper-silica catalyst preferred a relatively higher reaction temperature for the production of acrolein. The acrolein formation rate (normalized to the mass of copper) of 10Cu-DP reached $111.2 \mathrm{mmol} \cdot \mathrm{h}^{-1} \cdot \mathrm{g}_{\mathrm{Cu}}{ }^{-1}$ at $300{ }^{\circ} \mathrm{C}$, which was higher than that of active $10 \% \mathrm{Cu} / \mathrm{SBA}-15\left(75.5 \mathrm{mmol} \cdot \mathrm{h}^{-1} \cdot \mathrm{g}_{\mathrm{Cu}}{ }^{-1}, 300{ }^{\circ} \mathrm{C}\right.$ [20]) and $\mathrm{Cu} / \mathrm{SiO}_{2}\left(38.5 \mathrm{mmol} \cdot \mathrm{h}^{-1} \cdot \mathrm{gCu}^{-1}, 325^{\circ} \mathrm{C}\right.$ [29]) at similar reaction temperatures. Furthermore, this rate is comparable to that of CuPc/SBA-15 at a very high temperature $\left(475{ }^{\circ} \mathrm{C}, 90.5\right.$ $\mathrm{mmol} \cdot \mathrm{h}^{-1} \cdot \mathrm{g}_{\mathrm{Cu}^{-1}}$ ] [17], indicating the much lower "light off" temperature of our copper-silica catalyst. The 3CuMSN-E of mesoporous MCM-41 silica reported by Yang et al. [21] exhibited an acrolein formation rate of $236.0 \mathrm{mmol} \cdot \mathrm{h}^{-1} \cdot \mathrm{g}_{\mathrm{Cu}^{-1}}$ at $260{ }^{\circ} \mathrm{C}$, which is higher than our copper-mass-normalized value; however, the acrolein formation rate of $10 \mathrm{Cu}-\mathrm{DP}$ on a catalyst mass basis $\left(10.5 \mathrm{mmol} \cdot \mathrm{h}^{-1} \cdot \mathrm{gcat}^{-1}\right.$ at $\left.300{ }^{\circ} \mathrm{C}\right)$ is still larger than that of other catalysts (e.g., $7.2 \mathrm{mmol} \cdot \mathrm{h}^{-1} \cdot \mathrm{g}_{\mathrm{cat}^{-1}}$ at $300{ }^{\circ} \mathrm{C}$ for $10 \mathrm{Cu}$ / $\mathrm{Si}_{3} \mathrm{~N}_{4}-800$ [50]; $7.1 \mathrm{mmol} \cdot \mathrm{h}^{-1} \cdot \mathrm{g}_{\mathrm{cat}^{-1}}{ }^{-1}$ at $260{ }^{\circ} \mathrm{C}$ for 3CuMSN-E [21]; $7.6 \mathrm{mmol} \cdot \mathrm{h}^{-1} \cdot \mathrm{g}_{\mathrm{ca}}{ }^{-1}$ at $300{ }^{\circ} \mathrm{C}$ for $10 \% \mathrm{Cu} / \mathrm{SBA}-15$ [20], see Table S6). Thus, 10Cu-DP is among the best copper-based catalysts for the selective oxidation of propylene to produce acrolein.

\subsection{Structural characterization of the copper-silica catalysts}

To investigate the origin of the high reactivity of our copper-silica catalysts in acrolein formation, multiple characterizations were carried out to detect the differences in their structures before (fresh) and after the reaction (used). As shown in Fig. 2(a), no copper-containing phases characteristic of $\mathrm{CuO} / \mathrm{Cu}_{2} \mathrm{O} / \mathrm{Cu}$ were observed in the XRD patterns of fresh $10 \mathrm{Cu}-\mathrm{DP}, 5 \mathrm{Cu}-\mathrm{DP}$, or $15 \mathrm{Cu}-\mathrm{DP}$, indicating the absence of crystallized copper/copper oxide species in the samples prepared by deposition-precipitation before the reaction. In contrast, fresh 10Cu-IM showed distinct CuO peaks (PDF\#00-045-0937) with an average crystallite size of $18.3 \mathrm{~nm}$ as calculated by the Scherrer formula (Fig. S6(a)). On the other hand, the XRD pattern of $10 \mathrm{Cu}$-DP used at $300^{\circ} \mathrm{C}$ in Fig. 2(b) shows wide peaks at $36.5^{\circ}, 42.4^{\circ}, 61.6^{\circ}$, and $73.7^{\circ}(2 \theta)$, which were assigned to the (111), (200), (220), and (311) planes of $\mathrm{Cu}_{2} \mathrm{O}$ (PDF\#00-005-0667), respectively, and an average crystallite size of $2.8 \mathrm{~nm}$, while that of used 10Cu-IM shows similar but sharper $\mathrm{Cu}_{2} \mathrm{O}$ peaks and a larger size of $20.3 \mathrm{~nm}$ (Fig. S6(b)). In addition, we calculated the average crystallite sizes of the $\mathrm{Cu}_{2} \mathrm{O}$ species in the used catalysts using the Scherrer equation; the results are summarized in Table 1 . Clearly, as the $\mathrm{Cu}$ loading was increased from $5 \mathrm{Cu}-\mathrm{DP}$ to $15 \mathrm{Cu}-\mathrm{DP}$ and the reaction temperature was raised from 225 to $325^{\circ} \mathrm{C}$, the intensities of $\mathrm{Cu}_{2} \mathrm{O}$ peaks gradually became stronger (Fig. 2(b)). A slight increase in the $\mathrm{Cu}_{2} \mathrm{O}$ crystallite size from 2.5 to $3.5 \mathrm{~nm}$ was also observed, but this increase was much smaller than that of the used catalysts synthesized by the impregnation method (12.8 $\rightarrow 28.3 \mathrm{~nm}$ ). For both the $\mathrm{Cu}-\mathrm{DP}$ and $\mathrm{Cu}-\mathrm{IM}$ samples, cuprous oxide species were only observed after the propylene oxidation process. The combination of the XRD and catalytic performance data for these catalysts revealed that the small-sized copper-silica samples synthesized by the deposition precipitation approach exhibited higher catalytic activity in this reaction than the large-sized samples synthesized by the impregnation method under the same testing conditions.

The electronic and coordination structures of the copper species were analyzed using XAFS measurements. The XANES profiles of fresh $5 \mathrm{Cu}-\mathrm{DP}, 10 \mathrm{Cu}-\mathrm{DP}$, and $15 \mathrm{Cu}-\mathrm{DP}$ exhibit edge shapes similar to that of the a $\mathrm{CuO}$ reference (Fig. 3(a)), indicating its oxidized $\mathrm{Cu}^{2+}$ state before reaction. However, after the catalytic reaction, the used samples display edge shapes similar to that of the $\mathrm{Cu}_{2} \mathrm{O}$ reference (Fig. 3(c)), revealing the partial reduction of the copper species after pretreatment with hydrogen and the subsequent propylene oxidation process.

As shown in Fig. 3(b), the EXAFS spectra of the fresh copper-silica samples prepared by the deposition-precipitation method exhibit a prominent peak at approximately $1.9 \AA$, which is derived from the first shell of $\mathrm{Cu}-\mathrm{O}$ (Table 2). Here, the possibility of copper hydroxyl species cannot be excluded since $\mathrm{Cu}-\mathrm{OH}$ cannot be distinguished from $\mathrm{Cu}-\mathrm{O}$ in EXAFS. A second weak $\mathrm{Cu}-\mathrm{Cu}$ shell at approximately $3.0 \AA$ A (Table 2) can also be identified, which corresponds to the presence of $\mathrm{Cu}-\mathrm{O}-\mathrm{Cu}$ interactions in the $\mathrm{CuO}$ model. After the reaction, the copper spe- (a)

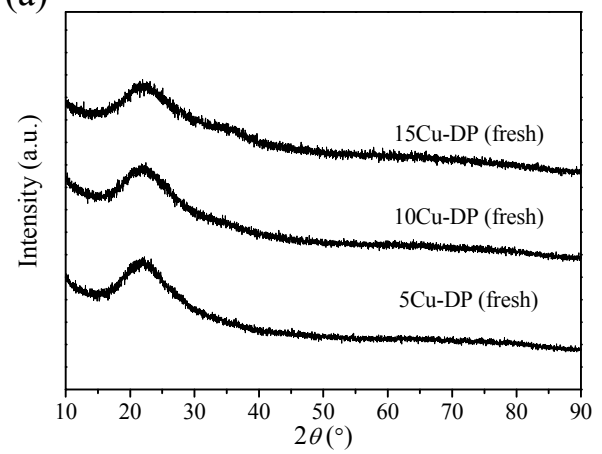

(b)

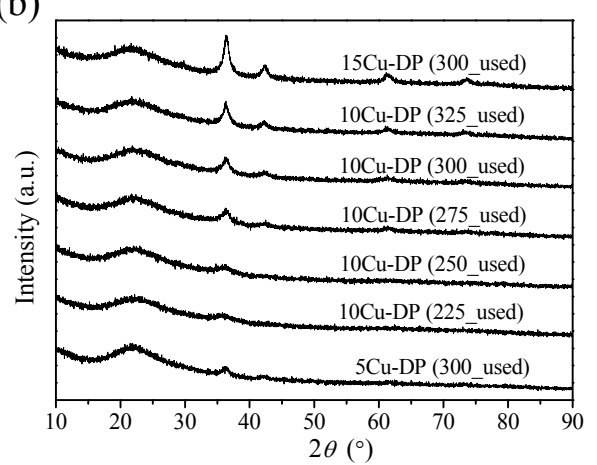

Fig. 2. XRD patterns of the copper-silica catalysts prepared by deposition-precipitation method. (a) Fresh; (b) used. 
(a)

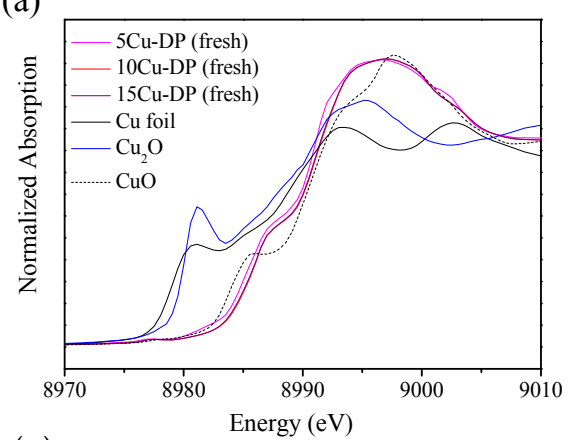

(c)

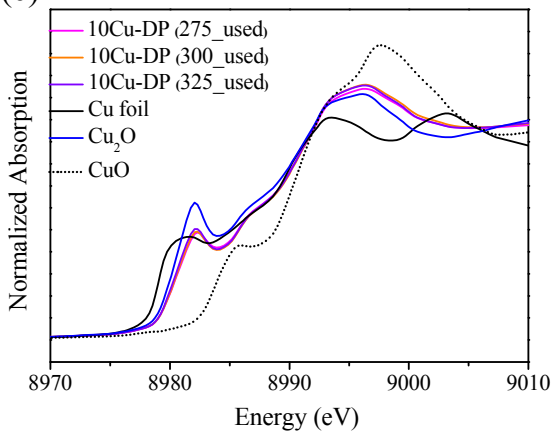

(b)

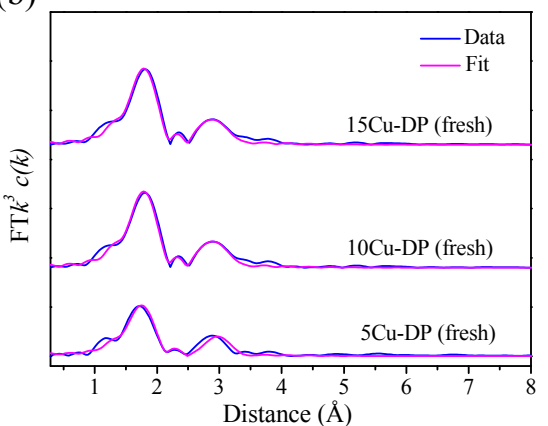

(d)

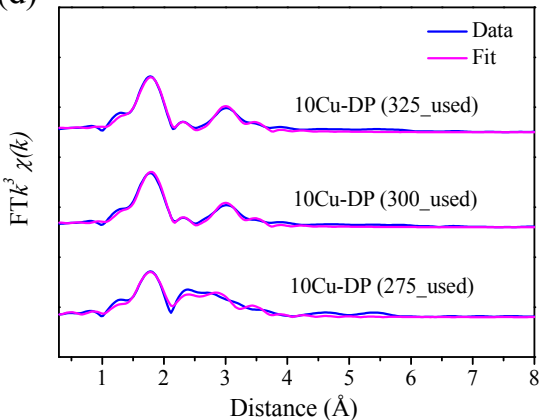

Fig. 3. Cu K-edge XANES profiles (a, c) and EXAFS fitting results (b, d) in R space for fresh (a, b) and used (c, d) copper-silica samples prepared by the deposition-precipitation method.

cies in used 10Cu-DP could fitted using a $\mathrm{Cu}_{2} \mathrm{O}$ model, i.e., a first $\mathrm{Cu}-\mathrm{O}$ shell at $1.9 \AA$, a second $\mathrm{Cu}-\mathrm{Cu}$ shell at $3.0 \AA$, and a third $\mathrm{Cu}-\mathrm{O}$ shell at 3.5-3.6 Å (Fig. 3(d), Table 3). Furthermore, the coordination numbers (CN) calculated for the high $\mathrm{R}$ shells ( $\mathrm{Cu}-\mathrm{O}$ and $\mathrm{Cu}-\mathrm{Cu}>2.5 \AA$ ) were significantly lower than those of the pure $\mathrm{CuO}$ and $\mathrm{Cu}_{2} \mathrm{O}$ model structures, indicating the small-size of the $\mathrm{CuO}_{x}$ species in both the fresh and used catalysts.

Figures 4(a) and 4(b) show aberration-corrected HAADF-STEM images of 10Cu-DP before and after reaction at $300{ }^{\circ} \mathrm{C}$. The TEM images of the fresh catalyst show the high dispersion of non-crystalline copper species with a narrow size distribution and an average size of $1.9 \pm 0.4 \mathrm{~nm}$ (additional images are provided in Fig. S7(a)). Although the vivid picture of copper species on the used 10Cu-DP sample demonstrated their enhanced crystallinity after the reaction, and with an average size of $2.2 \pm 0.4 \mathrm{~nm}$ (Figs. 4(b) and S7(b)), there is no significant growth of such copper oxide species after the catalytic reaction at $300{ }^{\circ} \mathrm{C}$ for $320 \mathrm{~min}$. This result indicated the high stability of the cluster size of the studied small-sized cop-

Table 2

EXAFS fitting results for fresh copper-silica samples with different $\mathrm{Cu}$ loadings.

\begin{tabular}{lccccc}
\hline \multirow{2}{*}{ Sample } & \multicolumn{2}{c}{$\mathrm{Cu}-\mathrm{O}$} & & \multicolumn{2}{c}{$\mathrm{Cu}-\mathrm{Cu}$} \\
\cline { 2 - 3 } \cline { 5 - 6 } & $R(\AA)$ & $\mathrm{CN}$ & & $R(\AA)$ & $\mathrm{CN}$ \\
\hline CuO & 1.948 & 4 & & 2.935 & 10 \\
5Cu-DP & $1.89 \pm 0.01$ & $2.9 \pm 0.2$ & & $2.99 \pm 0.02$ & $2.3 \pm 0.6$ \\
10Cu-DP & $1.93 \pm 0.01$ & $4.7 \pm 0.2$ & & $2.96 \pm 0.01$ & $3.1 \pm 0.6$ \\
15Cu-DP & $1.93 \pm 0.01$ & $4.7 \pm 0.2$ & & $2.96 \pm 0.01$ & $3.0 \pm 0.6$ \\
\hline
\end{tabular}

$R$ : distance; CN: coordination number; $\sigma^{2}$ (Debye-Waller factor) $=0.006$ $\AA^{2}(\mathrm{Cu}-0)$ or $0.015 \AA^{2}\left(\mathrm{Cu}-\mathrm{Cu}\right.$ ) for all the analyzed samples; $\Delta E_{0}$ (inner potential correction) $=9.1 \pm 0.3 \mathrm{eV}$ for all the analyzed samples. per-silica catalyst. Conversely, non-uniform copper oxide or cuprous oxide species (determined by HRTEM) were clearly observed for both fresh and used 10Cu-IM; these species formed both very small-sized $(\sim 2 \mathrm{~nm})$ species and bulky aggregates (Fig. S8), which may have resulted in the low conversion of $\mathrm{C}_{3} \mathrm{H}_{6}$ at $300{ }^{\circ} \mathrm{C}$ over this catalyst.

On the basis of the above XRD, XAFS, and HAADF-STEM data, we found that the present deposition-precipitation method favors the formation of a copper-silica catalyst with small-sized non-crystalline clusters, while the impregnation approach tends to form larger-sized crystalline particles, and that these copper-silica catalysts undergo a structural transformation from $\mathrm{CuO}$ (air, $400{ }^{\circ} \mathrm{C}$ ) to $\mathrm{Cu}_{2} \mathrm{O}\left(\mathrm{C}_{3} \mathrm{H}_{6}+\mathrm{O}_{2}, 300{ }^{\circ} \mathrm{C}\right)$ during the reaction (Fig. 4(c)).

\subsection{Investigation of the "structure-activity" relationship}

To investigate the effect of the copper species on acrolein

Table 3

EXAFS fitting results of used 10Cu-DP samples.

\begin{tabular}{lccccc}
\hline \multirow{2}{*}{ Sample } & \multicolumn{2}{c}{$\mathrm{Cu}-\mathrm{O}$} & & \multicolumn{2}{c}{$\mathrm{Cu}-\mathrm{Cu}$} \\
\cline { 2 - 3 } \cline { 5 - 6 } & $R(\AA)$ & $\mathrm{CN}$ & & $R(\AA)$ & $\mathrm{CN}$ \\
\hline $\mathrm{Cu}_{2} \mathrm{O}$ & 1.849 & 2 & & 3.019 & 12 \\
& 3.540 & 6 & & & \\
10Cu-DP-275-used & $1.87 \pm 0.01$ & $1.9 \pm 0.1$ & & $2.56 \pm 0.01$ & $3.1 \pm 1.2$ \\
& $3.51 \pm 0.02$ & $2.9 \pm 0.6$ & & $2.94 \pm 0.02$ & $3.3 \pm 1.6$ \\
10Cu-DP-300-used & $1.87 \pm 0.01$ & $2.3 \pm 0.1$ & & $3.00 \pm 0.01$ & $4.4 \pm 1.4$ \\
& $3.55 \pm 0.03$ & $2.0 \pm 0.7$ & & & \\
10Cu-DP-325-used & $1.87 \pm 0.01$ & $2.3 \pm 0.1$ & & $3.00 \pm 0.01$ & $4.8 \pm 1.5$ \\
& $3.55 \pm 0.02$ & $2.3 \pm 0.7$ & & & \\
\hline
\end{tabular}

$\sigma^{2}=0.005 \AA^{2}(\mathrm{Cu}-0)$ or $0.018 \AA^{2}(\mathrm{Cu}-\mathrm{Cu})$ for all analyzed samples; $\Delta E_{0}$ $=9.8 \mathrm{eV}$ for or all analyzed samples. 


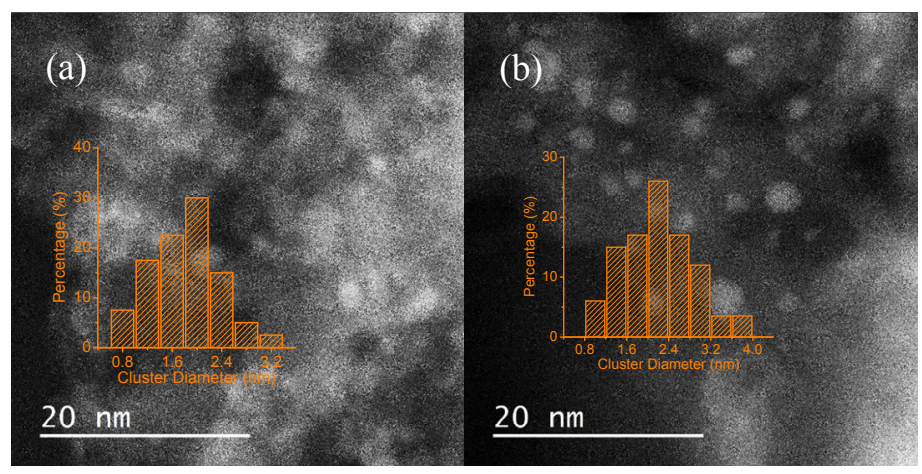

(c)

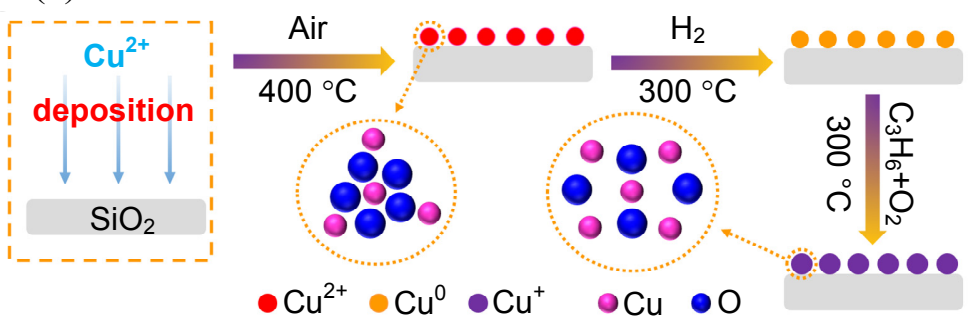

Fig. 4. Aberration-corrected HAADF-STEM images of (a) fresh and (b) used 10Cu-DP. (c) Schematic of the synthesis and structural transformation of 10Cu-DP.

production via the selective oxidation of propylene, in situ XRD was performed to trace the structural evolution of the copper-silica catalysts during the reaction. During the hydrogen pretreatment $\left(5 \% \mathrm{H}_{2} / \mathrm{Ar}\right)$ step, the diffraction patterns of 10Cu-DP were recorded under ambient conditions followed by in situ reduction with increasing temperature from 100 to 350 ${ }^{\circ} \mathrm{C}$. As shown in Fig. 5(a), the $\mathrm{Cu}^{0}(111)$ peak appeared at $250{ }^{\circ} \mathrm{C}$ and became more prominent as temperature was further increased, indicating that the copper oxide species could be reduced to metallic copper above $250^{\circ} \mathrm{C}$. This finding was in good agreement with the $\mathrm{H}_{2}$-TPR results (Fig. $\mathrm{S} 1$ and Table S5). After cooling the catalyst to $\sim 30{ }^{\circ} \mathrm{C}$ under the same reducing atmosphere, the characteristic peak of metallic $\mathrm{Cu}$ almost disappeared, probably due to redispersion of the crystallized copper species [51]. That is, the highly dispersed copper oxide clusters were gradually reduced to small crystalline copper species under a hydrogen atmosphere $\left(250-350{ }^{\circ} \mathrm{C}\right.$, short in duration) without sintering. Thus, when the heating was halted abruptly and the temperature dropped sharply, the small grains with high surface-to-volume ratios were more likely to migrate rapidly to and redisperse on the surface of the silica support, which had a high surface area. The interaction between the copper species and the silica support was thought to be the driving force for the redispersion process. These highly dispersed copper species were very stable at $30{ }^{\circ} \mathrm{C}$ under various atmospheres ( $\mathrm{Ar}$ or $\mathrm{C}_{3} \mathrm{H}_{6}+\mathrm{O}_{2}$, see Fig. 5(b)). When the reactant gas mixture $\left(\mathrm{C}_{3} \mathrm{H}_{6}+\mathrm{O}_{2}\right)$ was switched on and the testing temperature was raised from 30 to $300{ }^{\circ} \mathrm{C}$, a cuprous oxide $\left(\mathrm{Cu}_{2} \mathrm{O}\right)$ phase with a (111) peak at approximately $36.5^{\circ}$ was generated. Moreover, even after 320 min of continuous reaction, only the $\mathrm{Cu}_{2} \mathrm{O}$ phase was observed, without any observable growth in the average grain size (Fig. 5(b)).
Furthermore, we collected in situ XRD data for 10Cu-DP reacted at $250{ }^{\circ} \mathrm{C}$ under the same atmosphere (Fig. S9). A broader $\mathrm{Cu}_{2} \mathrm{O}$ (111) characteristic peak was generated at the same position $\left(36.5^{\circ}\right)$ and remained almost unchanged over $320 \mathrm{~min}$, indicating that the structure of $10 \mathrm{Cu}-\mathrm{DP}$ was very stable at a relatively low reaction temperature. These in situ XRD results demonstrate the structural transformation of silica-supported copper oxide clusters via the selective oxidation of propylene, i.e., small-sized copper oxide ( $\mathrm{CuO}$ ) species were first converted to a metallic copper $(\mathrm{Cu})$ phase during the hydrogen pretreatment, and then further transformed into partially oxidized cuprous oxide $\left(\mathrm{Cu}_{2} \mathrm{O}\right)$ clusters during the subsequent reaction process.

For comparison, the in situ XRD patterns of the impregnation-synthesized large-sized sample (10Cu-IM) were also collected to investigate the size effect in our copper-silica catalyst. Fig. 5(c) and 5(d) exhibit a similar $\mathrm{CuO}$ (fresh) $\rightarrow \mathrm{Cu}\left(\mathrm{H}_{2}\right) \rightarrow$ $\mathrm{Cu}_{2} \mathrm{O}\left(\mathrm{C}_{3} \mathrm{H}_{6}+\mathrm{O}_{2}\right)$ structural transformation; however, the 10Cu-IM patterns contained two distinctly different features: (1) The sharp peaks indicated a high degree of crystallinity and large average crystallite size of approximately $18.3 \mathrm{~nm}$, and (2) the XRD patterns obtained under the reaction conditions at 300 ${ }^{\circ} \mathrm{C}$ exhibited a mixture of both metallic $\mathrm{Cu}$ and partially oxidized $\mathrm{Cu}_{2} \mathrm{O}$ phases, rather than pure cuprous oxide. A previous report of a $\mathrm{Cs}^{+-} 5 \mathrm{wt} \% \mathrm{CuO}_{x} / \mathrm{SiO}_{2}(5.8 \mathrm{~nm})$ catalyst proposed that the $\mathrm{Cu}(0)$ was transformed into $\mathrm{Cu}_{2} \mathrm{O}$, part of which was further transformed into $\mathrm{CuO}$ after a longer reaction time, which exhibited a lower yield of acrolein [19]. We can infer that lower $\mathrm{Cu}$ loading on $\mathrm{SiO}_{2}$ is not conducive to the maintenance of $\mathrm{Cu}_{2} \mathrm{O}$, and that there exists a strong size-dependent effect between active copper species and the reactivity on acrolein formation directly from oxidation of propylene. 
(a)

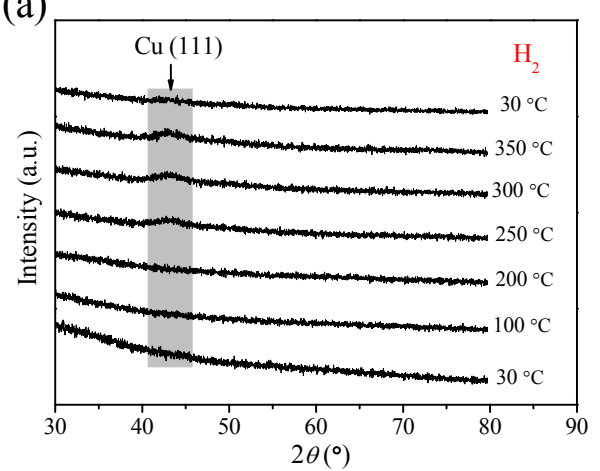

(c)

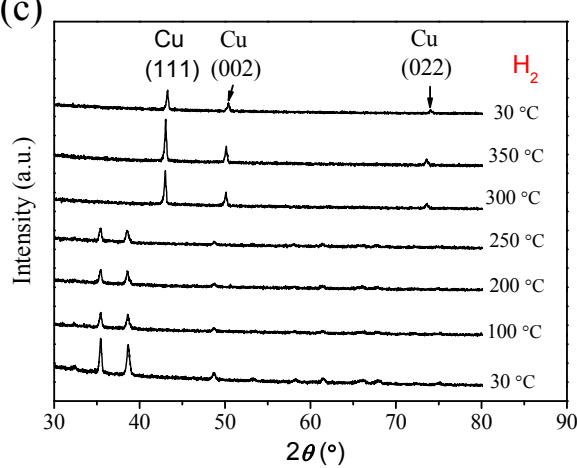

(b)

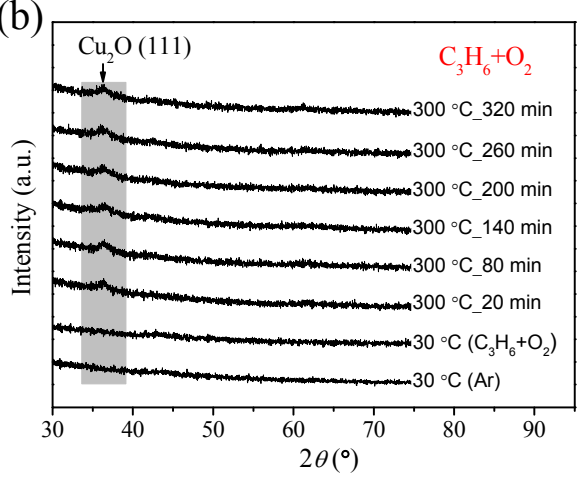

(d)

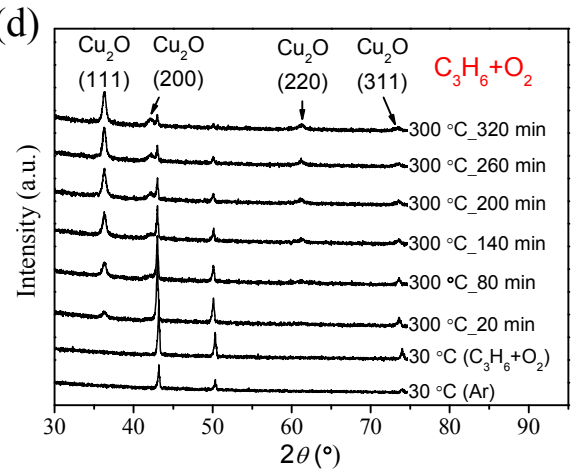

Fig. 5. Structural evolution of the $\mathrm{Cu} / \mathrm{SiO}_{2}$ catalysts. In situ XRD patterns of 10Cu-DP (a, b) and 10Cu-IM (c, d) during hydrogen reduction at different temperatures $(\mathrm{a}, \mathrm{c})$ and the propylene oxidation reaction $(\mathrm{b}, \mathrm{d})$.

The catalytic activity of the copper-silica catalyst was strongly associated with the structural evolution of the active copper species. Thus, to further investigate the reaction mechanism, in situ DB FTIR (Fig. S10) was used to trace and detect the surface adsorbents and reaction intermediates under the reaction conditions in the presence of propylene with oxygen at $300{ }^{\circ} \mathrm{C}$. As shown in Fig. S11(a), C-H bond vibrations corresponding to adsorbed propylene were observed under a $\mathrm{C}_{3} \mathrm{H}_{6}$ atmosphere; the peaks at 2968 and $2907 \mathrm{~cm}^{-1}$ (asymmetric C-H stretching vibrations of the $-\mathrm{CH}_{3}$ group) [52] increased gradually and stabilized in approximately $30 \mathrm{~min}$, revealing that propylene molecules can be adsorbed even on the pure $\mathrm{SiO}_{2}$ support. The introduction of the additional reactant $\mathrm{O}_{2}$ really helped the adsorption of propylene, but no other characteristic peaks were observed after a 90 min test (Fig. S11(b)), indicating that the adsorbed $\mathrm{C}_{3} \mathrm{H}_{6}$ could not be activated and further transformed into other products such as acrolein and $\mathrm{CO}_{2}$ on pure $\mathrm{SiO}_{2}$ under the mixed propylene/oxygen atmosphere at $300{ }^{\circ} \mathrm{C}$ (Fig. S12).

The in situ DB FTIR spectra of the small-sized copper-silica catalyst (10Cu-DP) were significantly different from those of the pure $\mathrm{SiO}_{2}$ support. Fig. 6(a) shows the propylene adsorption spectra on a reduced copper-silica sample $\left(300{ }^{\circ} \mathrm{C}, 30\right.$ $\mathrm{min})$, on which the $\mathrm{Cu}(\mathrm{II}) \rightarrow \mathrm{Cu}(0)$ reduction was verified by $\mathrm{H}_{2}$-TPR (Fig. S1) and in situ XRD (Fig. 5(a)) previously in this work. The IR bands at 2850-2970 and 3000-3110, 1620, and $680 \mathrm{~cm}^{-1}$, which corresponded to the $\mathrm{C}-\mathrm{H}$ stretching vibration of the $-\mathrm{CH}_{3}$ group, $\mathrm{C}-\mathrm{H}$ stretching vibration of $\mathrm{H}_{2} \mathrm{C}=\mathrm{CH}$, and $\mathrm{C}=\mathrm{C}$ stretching vibration [40,52-54] (detailed assignments are given in Table S7) gradually increased during the first 16 min and levelled off soon afterwards. The peaks at 1473, 1441, and $1396 \mathrm{~cm}^{-1}$ were assigned to $=\mathrm{CH}_{2}$ scissoring, $=\mathrm{CH}_{2}$ scissoring, and $\mathrm{C}-\mathrm{H}$ bending vibrations, respectively [40]. Importantly, a peak at $1419 \mathrm{~cm}^{-1}$ emerged once the $\mathrm{C}_{3} \mathrm{H}_{6}$ gas was introduced and became more intense with increasing collection time; this peak was ascribed to the $\mathrm{C}-\mathrm{H}$ asymmetric deformation of formate species [55]. 10Cu-DP showed significantly enhanced adsorption of $\mathrm{C}_{3} \mathrm{H}_{6}$ compared to the pure $\mathrm{SiO}_{2}$ support under the same testing conditions, suggesting that the introduction of copper enhanced the adsorption capacity of propylene.

To investigate the subsequent oxidation process, the same amount of $\mathrm{O}_{2}$ was added simultaneously after 30 min of $\mathrm{C}_{3} \mathrm{H}_{6}$ adsorption. Figure 6(b) shows that a strong adsorption peak at $1376 \mathrm{~cm}^{-1}$ corresponding to the methyl symmetrical $\mathrm{C}-\mathrm{H}$ bending vibration on $\mathrm{Cu}(\mathrm{I})$ and a relatively weaker characteristic band at $1548 \mathrm{~cm}^{-1}$ ascribed to $\mathrm{C}=\mathrm{C}$ interacting with $\mathrm{Cu}(\mathrm{I})$ were observed, indicating that the oxygen could easily adsorb on the surface of the reduced copper(0) species, resulting in the formation of partially oxidized $\mathrm{Cu}_{2} \mathrm{O}$ species under the reaction atmosphere $\left(\mathrm{C}_{3} \mathrm{H}_{6}+\mathrm{O}_{2}\right)$. These findings were consistent with the in situ XRD results (Fig. 5(b)) [40,43]. The band at 2968 $\mathrm{cm}^{-1}$ disappeared rapidly, and simultaneously, a new band at $2981 \mathrm{~cm}^{-1}$, which was attributed to the $\mathrm{C}-\mathrm{C}-\mathrm{H}$ stretching vibration of the surface allyl intermediate $\left(\mathrm{CH}_{2}=\mathrm{CHCH}_{2}{ }^{*}\right)$, appeared and grew stronger. This demonstrated that the propylene adsorbed on the copper-silica catalyst was activated; this was considered to be the first step in catalyzing the propylene-selective oxidation reaction and was crucial to subsequent the processes on the catalyst surface [56]. Moreover, the $\mathrm{C}=\mathrm{O}$ stretching vibration band of $-\mathrm{HC}=\mathrm{O}$ at $1731 \mathrm{~cm}^{-1}$ and $\mathrm{C}-\mathrm{H}$ 
(a)
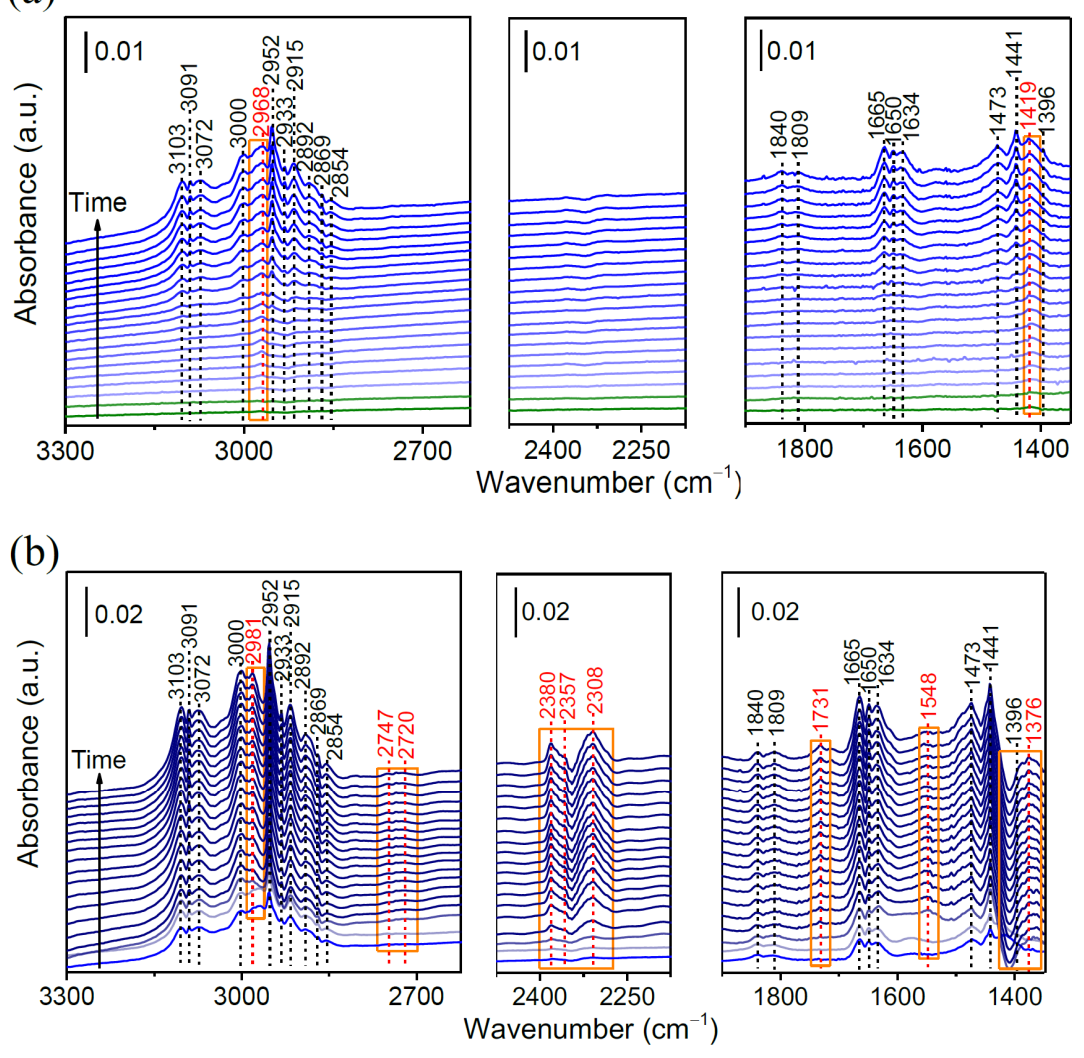

Fig. 6. Dissociation adsorption ability of $10 \mathrm{Cu}-\mathrm{DP}$. In situ DB-FTIR results for $10 \mathrm{Cu}-\mathrm{DP}$ during (a) propylene adsorption at $300{ }^{\circ} \mathrm{C}$ under a flowing mixture of propylene and nitrogen gases at a time on stream of 1, 2, 3, 4, 5, 6, 7, 8, 9, 10, 12, 14, 16, 18, 20, 22, 24, 26, 28, and 30 min $(0.01$ g catalyst, $\mathrm{C}_{3} \mathrm{H}_{6}: \mathrm{N}_{2}=2.5: 90,92.5 \mathrm{~mL} \cdot \mathrm{min}^{-1}, 1 \mathrm{~atm}$ ), and (b) propylene and oxygen coadsorption at $300{ }^{\circ} \mathrm{C}$ under a flowing mixture of propylene, oxygen, and nitrogen gases at a time on stream of $1,5,10,15,20,25,30,35,40,45,50,55,60,65,70,75,80,85$, and 90 min $\left(0.01\right.$ g catalyst, $\mathrm{C}_{3} \mathrm{H}_{6}: \mathrm{O}_{2}: \mathrm{N}_{2}=$ 2.5:2.5:90, $\left.95 \mathrm{~mL} \cdot \mathrm{min}^{-1}, 1 \mathrm{~atm}\right)$.

stretching vibration bands of $-\mathrm{HC}=0$ at 2720 and $2747 \mathrm{~cm}^{-1}$ were clearly detected once the surface allyl intermediate $\left(\mathrm{CH}_{2}=\mathrm{CHCH}_{2}{ }^{*}\right)$ was observed, confirming the formation of acrolein $[57,58]$. The $\mathrm{C}-\mathrm{H}$ asymmetric deformation peak of the formate species vanished within $5 \mathrm{~min}$, accompanied by the appearance of $\mathrm{CO}_{2}$ in the region $2250-2400 \mathrm{~cm}^{-1}[53,55]$. From the results in Fig. 6, it can be inferred that the selective oxidation of propylene on our small-sized copper-silica catalyst probably proceeds via a Mars and van Krevelen mechanism, in which the adsorbed $\mathrm{C}_{3} \mathrm{H}_{6}$ is effectively activated to form an intermediate species $\left(\mathrm{CH}_{2}=\mathrm{CHCH}_{2}{ }^{*}\right)$ on the surface of copper-silica catalyst, and reaction between the intermediate and a neighboring oxygen atom from the as-formed $\mathrm{Cu}_{2} \mathrm{O}$ species can take place to form acrolein and $\mathrm{CO}_{2}$ during the catalytic process, as reported by Ponec et al. [59,60]. Thus, a possible pathway for acrolein formation has experienced such a process:

$$
\mathrm{CH}_{2}=\mathrm{CH}-\mathrm{CH}_{3} \stackrel{-[\mathrm{H}]}{\longrightarrow} \mathrm{CH}_{2}=\mathrm{CH}-\mathrm{CH}_{2} * \stackrel{+[\mathrm{O}]-[\mathrm{H}]}{\longrightarrow} \mathrm{CH}_{2}=\mathrm{CH}-\mathrm{CHO}
$$

The large-sized 10Cu-IM sample with much lower activity was also examined during the selective oxidation of $\mathrm{C}_{3} \mathrm{H}_{6}$ for comparison to 10Cu-DP. In Fig. 7(a), similar peaks were observed during the $\mathrm{C}_{3} \mathrm{H}_{6}$ adsorption process at $300{ }^{\circ} \mathrm{C}$, implying that the copper non-uniformly on the silica via the impregnation method could enhance the adsorption of $\mathrm{C}_{3} \mathrm{H}_{6}$. In Fig. 7(b), new peaks similar to those of 10Cu-DP were also observed when $\mathrm{O}_{2}$ was introduced. However, some clear differences were observed between these two catalysts in the DB-FTIR measurements. For 10Cu-IM, the newly generated peaks were significantly weaker than those of $10 \mathrm{Cu}$-DP. A very broad peak at $1376 \mathrm{~cm}^{-1}$ assigned to the methyl symmetrical $\mathrm{C}-\mathrm{H}$ bending vibration on $\mathrm{Cu}(\mathrm{I})$ was detected, implying that the large-sized copper on $\mathrm{SiO}_{2}$ required more time to be oxidized to $\mathrm{Cu}_{2} \mathrm{O}$, in agreement with the in situ XRD results (Fig. 5(d)). Additionally, the peak at $2968 \mathrm{~cm}^{-1}$ was still present, and the peak of surface allyl intermediate $\left(\mathrm{CH}_{2}=\mathrm{CHCH}_{2}{ }^{*}\right)$ at $2981 \mathrm{~cm}^{-1}$ was weaker even after $90 \mathrm{~min}$ of reaction, implying that abstraction of a hydrogen from $\mathrm{C}_{3} \mathrm{H}_{6}$ was more difficult on the surface of the large-size copper-silica catalyst. Only the $\mathrm{C}=0$ stretching vibration band for $-\mathrm{HC}=0$ at $1731 \mathrm{~cm}^{-1}$ was observed, and the peak at $1419 \mathrm{~cm}^{-1}$ disappeared almost after $70 \mathrm{~min}$. The peaks related to $\mathrm{CO}_{2}$ species emerged slowly, indicating that it was difficult for the allylic intermediate to react with oxygen from the large-sized $\mathrm{Cu}_{2} \mathrm{O}$ to form the products. The above results show that both 10Cu-DP and 10Cu-IM can adsorb large amounts of $\mathrm{C}_{3} \mathrm{H}_{6}$, which can clearly be detected by DB-FTIR, and that the small-sized $\mathrm{Cu}(0)$ of $10 \mathrm{Cu}$-DP can more easily be oxidized to $\mathrm{Cu}_{2} \mathrm{O}$ to induce the formation of acrolein from the adsorbed allylic intermediate. In contrast, no distinct differences between 
(a)
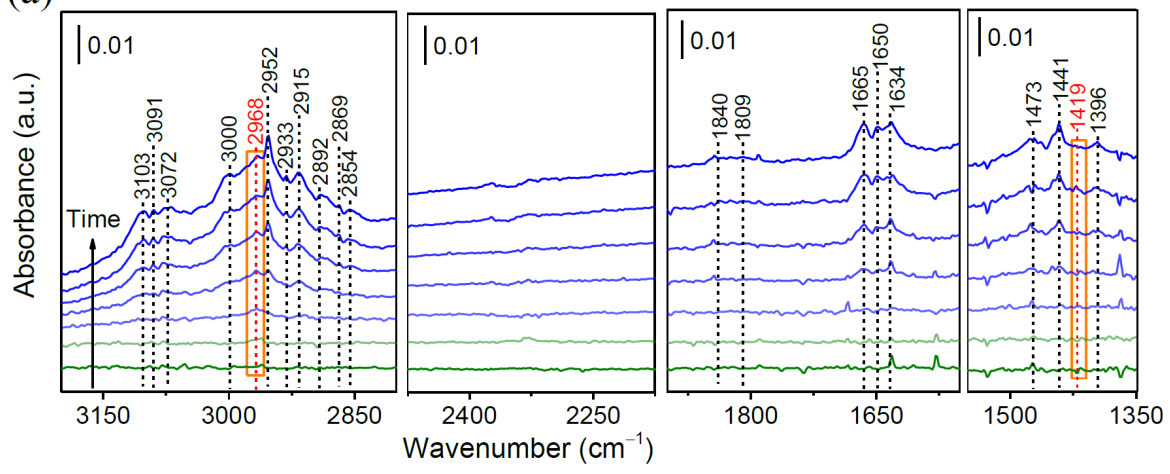

(b)
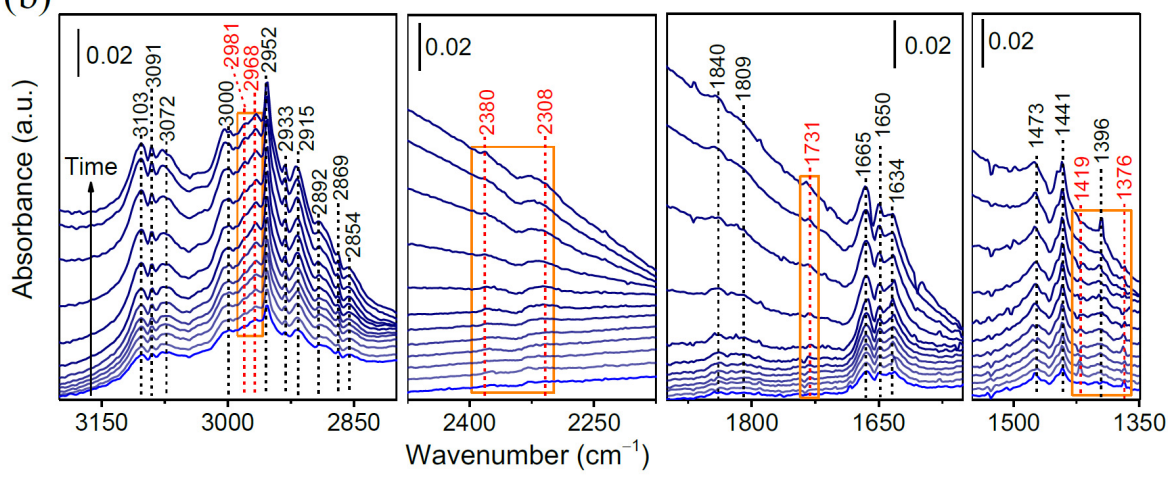

Fig. 7. Dissociation adsorption ability of $10 \mathrm{Cu} / \mathrm{SiO}_{2}$-IM. In situ DB-FTIR results for $10 \mathrm{Cu} / \mathrm{SiO}_{2}$-IM during (a) propylene adsorption at $300{ }^{\circ} \mathrm{C}$ under a

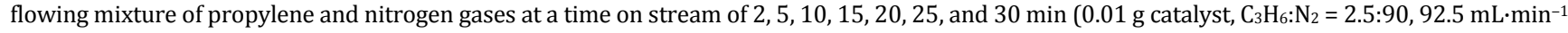
$1 \mathrm{~atm}$ ), and (b) propylene and oxygen coadsorption at $300{ }^{\circ} \mathrm{C}$ under a flowing mixture of propylene, oxygen, and nitrogen gases with a time on stream of $1,5,10,15,20,30,40,50,60,70,80$, and $90 \mathrm{~min}\left(0.01 \mathrm{~g}\right.$ catalyst, $\left.\mathrm{C}_{3} \mathrm{H}_{6}: \mathrm{O}_{2}: \mathrm{N}_{2}=2.5: 2.5: 90,95 \mathrm{~mL} \cdot \mathrm{min}^{-1}, 1 \mathrm{~atm}\right)$.

these two samples were observed in the single beam FTIR results in Fig. S13 and Fig. S14, mainly due to the influence of the gas-phase $\mathrm{C}_{3} \mathrm{H}_{6}$ peaks.

In addition, in the $3500-3800 \mathrm{~cm}^{-1}$ region of the in situ DB FTIR spectra (Fig. S15), silicon hydroxyls (Si-O-H) and copper hydroxyls $(\mathrm{Cu}-\mathrm{O}-\mathrm{H})$ were clearly detected on the $10 \mathrm{Cu}-\mathrm{DP}$ and 10Cu-IM samples after their activation with $\mathrm{H}_{2}$. As the reaction time was increased, the amount of copper hydroxyl groups gradually decreased, whereas no reaction occurred between the pure support and the gas mixture $\left(\mathrm{C}_{3} \mathrm{H}_{6}+\mathrm{O}_{2}\right)$ (Fig. S12). This result implied that the copper hydroxyls $(\mathrm{Cu}-\mathrm{O}-\mathrm{H})$ very likely affected the catalytic performance. Similarly, our previous work reported that surface copper hydroxyls were strongly related to acrolein selectivity, and that they favored the generation of $\mathrm{CO}_{2}$ at the beginning of the reaction and thus leading to an induction period [50]. The copper hydroxyls may have activated the surface reaction for the generation of $\mathrm{CO}_{2}$ at the beginning of this reaction, thus resulting in lower acrolein selectivity, followed by a gradual increase in acrolein selectivity accompanied by a decrease in copper hydroxyl groups (Fig. 1(c) and Fig. S15). On the other hand, the propylene conversion of 10Cu-DP decreased slowly throughout the whole reaction process, which could be attributed to the sintering of the catalyst under continuous high temperature reaction. However, the propylene conversion was still six times higher than that of the larger $10 \mathrm{Cu}$-IM catalyst, confirming that the small-sized cuprous oxide clusters enhanced the catalytic reactivity in propylene-selective oxidation.

As discussed as above, the small-sized $\mathrm{Cu}_{2} \mathrm{O}$ species (10Cu-DP) exhibited better catalytic activity than their larger counterparts (10Cu-IM) for the selective oxidation of propylene to acrolein. Additionally, the copper dispersion is directly associated with the number of active species on the copper-silica catalysts. Hence, we applied an $\mathrm{N}_{2} \mathrm{O}$-titration approach to determine the amount of surface copper(I) in each sample. As shown in Fig. 8, the calculated $\mathrm{Cu}(\mathrm{I})$ dispersion for $10 \mathrm{Cu}-\mathrm{DP}$ $(56 \%)$ was much higher than that of $10 \mathrm{Cu}-\mathrm{IM}(8 \%)$, in accordance with the higher activity of the former in the formation of acrolein (Table 1).

\section{Acknowledgments}

We thank Dr. Shuangquan Hu (Evonik Industries) for his kind help on supply of high surface-area silica support.

\section{Conclusions}

In summary, a controllable deposition-precipitation method was applied to immobilize small-sized and chemically stable copper oxide clusters on a silica support using $\mathrm{Na}_{2} \mathrm{CO}_{3}$ as a precipitating agent. The fabrication of uniform and small-sized copper-silica catalysts was more facile using the deposi- 


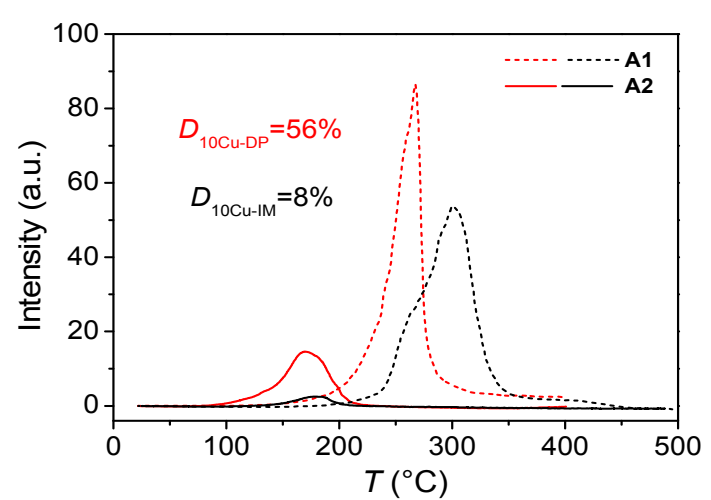

Fig. 8. $\mathrm{H}_{2}$-TPR profiles of $10 \mathrm{Cu}$-DP and $10 \mathrm{Cu}-\mathrm{IM}$. Dashed and solid lines are the hydrogen consumption profiles measured for the first (after $\mathrm{O}_{2}$ pretreatment) and second (after $\mathrm{N}_{2} \mathrm{O}$ oxidation) runs, respectively.

tion-precipitation approach than the incipient wetness impregnation method, especially for high loading ( $\geq 10 \mathrm{wt} \%$ ) copper-based catalysts. Moreover, the selection of a silica material with a high surface area was beneficial to the dispersion and stabilization of cuprous oxide clusters, which exhibited high cluster size stability even after $320 \mathrm{~min}$ of reaction at 300 ${ }^{\circ} \mathrm{C}$. Thus, outstanding catalytic activity in the generation of acrolein via selective oxidation of propylene was obtained over this active copper-silica catalyst. In particular, the $10 \mathrm{wt} \% \mathrm{Cu}$ sample showed excellent catalytic activity with $25.5 \%$ propylene conversion and $66.8 \%$ acrolein selectivity at $300{ }^{\circ} \mathrm{C}$, resulting in a very high acrolein yield of $17.0 \%$ and an acrolein formation rate of $111.2 \mathrm{mmol} \cdot \mathrm{h}^{-1} \cdot \mathrm{gCu}^{-1}$ or $10.5 \mathrm{mmol} \cdot \mathrm{h}^{-1} \cdot \mathrm{g}_{\mathrm{cat}}{ }^{-1}$ at $300{ }^{\circ} \mathrm{C}$. The structural evolution of the catalyst during the reaction was thoroughly explored using multiple characterization techniques. The combination of in situ XRD and in situ DB-FTIR demonstrated that the adsorbed $\mathrm{C}_{3} \mathrm{H}_{6}$ was effectively activated to form intermediate species $\left(\mathrm{CH}_{2}=\mathrm{CHCH}_{2}{ }^{*}\right)$ on the surface of the small-sized copper-silica sample, and that the intermediate reacts with neighboring oxygen atoms from the as-formed $\mathrm{Cu}_{2} \mathrm{O}$ species to form acrolein and $\mathrm{CO}_{2}$. Furthermore, the small-sized cuprous oxide species were identified as the active sites for the generation of acrolein at $300{ }^{\circ} \mathrm{C}$. This work not only offers a facile method for the preparation of highly efficient supported copper catalysts, but also provides a solid understanding of the structure-activity relationship of cuprous oxide clusters in the acrolein formation reaction.

\section{References}

[1] J. L. Callahan, R. K. Grasselli, E. C. Milberger, H. A. Strecker, Ind. Eng. Chem. Prod. Res. Dev., 1970, 9, 134-142.

[2] T. A. Nijhuis, M. Makkee, J. A. Moulijn, B. M. Weckhuysen, Ind. Eng. Chem. Res., 2006, 45, 3447-3459.

[3] L. Liu, X. P. Ye, J. J. Bozell, ChemSusChem, 2012, 5, 1162-1180.

[4] Y. H. Han, W. Ueda, Y. Moro-Oka, Appl. Catal. A, 1999, 176, 11-16.

[5] D. T. Duc, H. N. Ha, R. Fehrmann, A. Riisager, M. T. Le, Res. Chem. Intermed., 2011, 37, 605-616.

[6] K. Schuh, W. Kleist, M. Høj, V. Trouillet, A. D. Jensen, J. D. Grunwaldt, Chem. Commun., 2014, 50, 15404-15406.

[7] Z. Zhai, M. Wütschert, R. B. Licht, A. T. Bell, Catal. Today, 2016, 261, 146-153.
[8] L. Bui, R. Chakrabarti, A. Bhan, ACS Catal., 2016, 6, 6567-6580.

[9] P. Sprenger, W. Kleist, J.-D. Grunwaldt, ACS Catal., 2017, 7, 5628-5642.

[10] G. I. Panov, E. V. Starokon, M. V. Parfenov, B. Wei, V. I. Sobolev, L. V. Pirutko, ACS Catal., 2018, 8, 1173-1177.

[11] P. Sprenger, M. Stehle, A. Gaur, A. M. Gänzler, D. Gashnikova, W. Kleist, J.-D. Grunwaldt, ACS Catal., 2018, 8, 6462-6475.

[12] L. M. Molina, S. Lee, K. Sell, G. Barcaro, A. Fortunelli, B. Lee, S. Seifert, R. E. Winans, J. W. Elam, M. J. Pellin, I. Barke, V. Oeynhausen, Y. Lei, R. J. Meyer, J. A. Alonso, A. F. Rodríguez, A. Kleibert, S. Giorgio, C. R. Henry, K.-H. Meiwes-Broer, S. Vajda, Catal. Today, 2011, 160, 116-130.

[13] C. R. Adams, T. J. Jennings, J. Catal., 1963, 2, 63-68.

[14] C. R. Adams, T. J. Jennings, J. Catal., 1964, 3, 549-558.

[15] Y. Wang, H. Chu, W. Zhu, Q. Zhang, Catal. Today, 2008, 131, 496-504.

[16] W. Zhu, Q. Zhang, Y. Wang, J. Phys. Chem. C, 2008, 112, 7731-7734.

[17] H. Tüysüz, J. L. Galilea, F. Schüth, Catal. Lett., 2009,131, 49-53.

[18] J. Huang, M. Haruta, Res. Chem. Intermed., 2012, 38, 1-24.

[19] J. He, Q. Zhai, Q. Zhang, W. Deng, Y. Wang, J. Catal., 2013, 299, 53-66.

[20] C.-H. Liu, N.-C. Lai, J.-F. Lee, C.-S. Chen, C.-M. Yang, J. Catal., 2014, 316, 231-239.

[21] N.-C. Lai, M.-C. Tsai, C.-H. Liu, C.-S. Chen, C.-M. Yang, J. Catal., 2018, 365, 411-419.

[22] M. Tonelli, M. Aouine, L. Massin, V. B. Baca, J. M. M. Millet, Catal. Sci. Technol., 2017, 7, 4629-4639.

[23] J. Yu, L. Kevan, J. Phys. Chem., 1991, 95, 6648-6653.

[24] J. Lu, M. Luo, H. Lei, X. Ba, C. Li, J. Catal., 2002, 211, 552-555.

[25] L. Yang, J. He, Q. Zhang, Y. Wang, J. Catal., 2010, 276, 76-84.

[26] K. L. Bøyesen, T. Kristiansen, K. Mathisen, Catal. Today, 2015, 254, 21-28.

[27] W. Song, D. M. Perez Ferrandez, L. van Haandel, P. Liu, T. A. Nijhuis, E. J. M. Hensen, ACS Catal., 2015, 5, 1100-1111.

[28] H. Chu, L. Yang, Q. Zhang, Y. Wang, J. Catal., 2006, 241, 225-228.

[29] O. P. H. Vaughan, G. Kyriakou, N. Macleod, M. Tikhov, R. M. Lambert, J. Catal., 2005, 236, 401-404.

[30] I. Onal, D. Düzenli, A. Seubsai, M. Kahn, E. Seker, S. Senkan, Top. Catal., 2010, 53, 92-99.

[31] W. T. Wei, Y. Z. Lu, W. Chen, S. W. Chen, J. Am. Chem. Soc., 2011, 133, 2060-2063.

[32] P. Maity, S. Yamazoe, T. Tsukuda, ACS Catal., 2013, 3, 182-185.

[33] W.-W. Wang, W.-Z. Yu, P.-P. Du, H. Xu, Z. Jin, R. Si, C. Ma, S. Shi, C.-J. Jia, C.-H. Yan, ACS Catal., 2017, 7, 1313-1329.

[34] B. Yang, C. Liu, A. Halder, E. C. Tyo, A. B. F. Martinson, S. Seifert, P. Zapol, L. A. Curtiss, S. Vajda, J. Phys. Chem. C, 2017, 121, 10406-10412.

[35] K. Judai, S. Abbet, A. S. Wörz, U. Heiz, C. R. Henry, J. Am. Chem. Soc., 2004, 126, 2732-2737.

[36] H. Yin, H. Tang, D. Wang, Y. Gao, Z. Tang, ACS Nano, 2012, 6, 8288-8297.

[37] Y. Attia, M. Samer, Renew. Sustain. Energy Rev., 2017, 79, 878-892.

[38] M. Zhou, M. Yang, X. Yang, X. Zhao, L. Sun, W. Deng, A. Wang, J. Li, T. Zhang, Chin. J. Catal., 2020, 41, 524-532.

[39] S. Colussi, P. Fornasiero, A. Trovarelli, Chin. J. Catal., 2020, 41, 938-950.

[40] W. Su, S. Wang, P. Ying, Z. Feng, C. Li, J. Catal., 2009, 268, 165-174.

[41] J. B. Reitz, E. I. Solomon, J. Am. Chem. Soc., 1998, 120, 11467-11478.

[42] S. Belin, C. L. Bracey, V. Briois, P. R. Ellis, G. J. Hutchings, T. I. Hyde, G. Sankar, Catal. Sci. Technol, 2013, 3, 2944-2957.

[43] H.-C. Wu, C.-S. Chen, C.-M. Yang, M.-C. Tsai, J.-F. Lee, ACS Appl. Ma- 


\section{Graphical Abstract}

Chin. J. Catal., 2021, 42: 320-333 doi: 10.1016/S1872-2067(20)63636-1

Small-sized cuprous oxide species on silica boost acrolein formation via selective oxidation of propylene

Ling-Ling Guo, Jing Yu, Wei-Wei Wang, Jia-Xu Liu*, Hong-Chen Guo, Chao Ma *, Chun-Jiang Jia *, Jun-Xiang Chen, Rui Si *

Shanghai Institute of Applied Physics, Chinese Academy of Sciences; Shanghai Synchrotron Radiation Facility, Zhangjiang Laboratory; Shanghai Institute of Measurement and Testing Technology; Shandong University; Dalian University of Technology; Hunan University; TILON Group Technology Limited; University of Chinese Academy of Science

Small-sized copper oxide clusters have been fabricated on silica for the efficient formation of acrolein via the selective oxidation of propylene. The reaction mechanism was explored using in situ X-ray diffraction and in situ dual beam Fourier transform infrared spectroscopy.

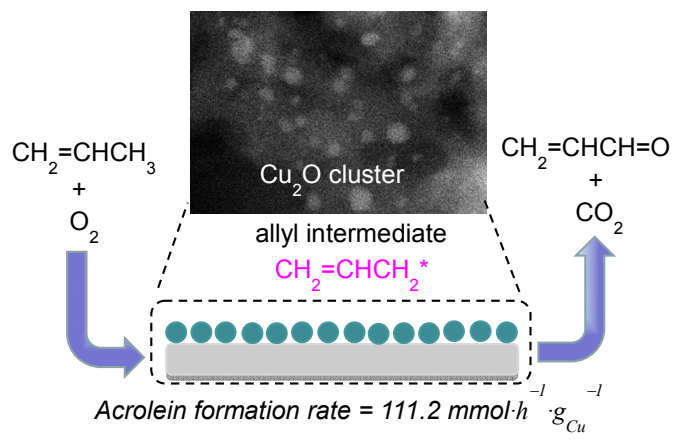

ter. Interfaces, 2018, 10, 38547-38557.

[44] J. Liu, J. Wang, W. Zhou, C. Miao, G. Xiong, Q. Xin, H. Guo, Chin. J. Catal., 2017, 38, 13-19.

[45] J. Liu, N. He, W. Zhou, L. Lin, G. Liu, C. Liu, J. Wang, Q. Xin, G. Xiong, H. Guo, Catal. Sci. Technol, 2018, 8, 4018-4029.

[46] L. Wang, H. Li, W. Zhang, X. Zhao, J. Qiu, A. Li, X. Zheng, Z. Hu. R. Si, J. Zeng, Angew. Chem., 2017, 129, 4790-4796.

[47] X. Yin, H.-J. Wang, S.-F. Tang, X.-L. Lu, M. Shu, R. Si, T.-B. Lu, Angew. Chem. Int. Ed., 2018, 57, 9382-9386.

[48] S. T. Oyama, X. Zhang, J. Lu, Y. Gu, T. Fujitani, J. Catal., 2008, 257, $1-4$.

[49] Y. Cao, W. Fu, Z. Ren, Z. Sui, J. Zhou, J. Luo, X. Duan, X. Zhou, AIChE J., 2019, 66, 4 .

[50] L.-L. Guo, J. Yu, M. Shu, L. Shen, R. Si, J. Catal., 2019, 380, 352-365.

[51] K. Morgan, A. Goguet, C. Hardacre, ACS Catal., 2015, 5, 3430-3445.

[52] J.-G. Radziszewski, J.-W. Downing, M.-S. Gudipati, V. Balaji, E.-W.
Thulstrup, J. Michl, J. Am. Chem. Soc., 1996, 118, 10275-10284.

[53] M. Xin, I.-C. Hwang, S.-I. Woo, J. Phys. Chem. B, 1997, 101, 9005-9009.

[54] J. Liu, Q. Zhao, X. Li, J. Chen, D. Zhang, Appl. Catal. B, 2015, 165, 519-528.

[55] L. Ma, C.-Y. Seo, X. Chen, K. Sun, J.-W. Schwank, Appl. Catal. B, 2018, 222, 44-58.

[56] C. Zhao, I. E. Wachs, J. Phys. Chem. C, 2008, 112, 11363-11372.

[57] D.-A. Esan, Y. Ren, X. Feng, M. Trenary, J. Phys. Chem. C, 2017, 121, 4384-4392.

[58] K.-H. Dostert, C.-P. O’Brien, F. Mirabella, F. Ivars-Barceló, S. Attia, E. Spadafora, S. Schauermann, H.-J. Freund, ACS Catal., 2017, 7, 5523 $-5533$.

[59] C. Doornkamp, M. Clement, V. Ponec, Appl. Catal. A, 1999, 188, 325-336.

[60] C. Doornkamp, V. Ponec, J. Mol. Catal. A, 2000, 162, 19-32.

\section{负载于二氧化硅上的小尺寸氧化亚铜物种促进丙烯选择性氧化生成丙烯醛}

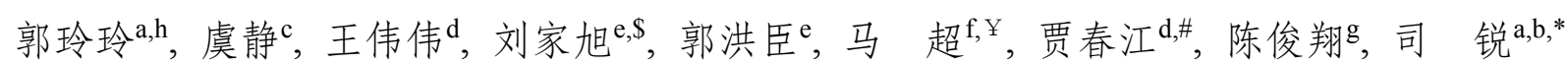
a中国科学院上海应用物理研究所, 上海 201800

b张江实验室上海同步辐射光源, 上海 201204

c上海市计量测试技术研究院, 上海200233

$\mathrm{d}$ 山东大学化学与化工学院胶体与界面化学教育部重点实验室, 特种功能聚集体材料教育部重点实验室, 山东济南250100 '大连理工大学化学与化工学院, 精细化工国家重点实验室, 辽宁大连 116023

f湖南大学材料科学与工程学院, 湖南长沙 410082

$\mathrm{g}$ 泰逻集团科技有限公司中国事业部, 上海 200090

$\mathrm{h}$ 中国科学院大学, 北京 100049

摘要: 氧化物负载的含铜材料是丙烯选择性氧化制备丙烯醛的理想催化剂, 一直以来都受到人们的广泛关注. 然而, 对于 该催化体系的结构与性能之间的关系仍不是很清楚. 因此, 我们以碳酸钠为沉淀剂, 通过沉积沉淀法将铜负载于高比表面 的二氧化硅载体上, 从而得到了均匀分散且小尺寸的 $\mathrm{Cu} / \mathrm{SiO}_{2}$ 催化剂. 另外, 采用浸渍法制得了相同负载量的分散不均匀、 大尺寸的 $\mathrm{Cu} / \mathrm{SiO}_{2}$ 催化剂. 丙烯选择性氧化反应活性测试发现, 沉积沉淀法制备的催化剂比浸渍法制备的更有利于丙烯醛 的生成, 表现出了优异的催化性能: 在 $300{ }^{\circ} \mathrm{C}$ 反应时, 丙烯的转化率达到 $25.5 \%$, 丙烯醛的选择性达到 $66.8 \%$, 对应的丙烯醛 的生成速率高达 $10.5 \mathrm{mmol} \cdot \mathrm{h}^{-1} \cdot \mathrm{g}_{\mathrm{cat}}{ }^{-1}$ 或 $111.2 \mathrm{mmol} \cdot \mathrm{h}^{-1} \cdot \mathrm{g}_{\mathrm{Cu}}{ }^{-1}$, 远远超出了浸渍法制备的催化剂性能 $\left(1.7 \mathrm{mmol} \cdot \mathrm{h}^{-1} \cdot \mathrm{g}_{\mathrm{cat} .}{ }^{-1}\right.$ 或 17.2 
$\mathrm{mmol} \cdot \mathrm{h}^{-1} \cdot \mathrm{g}_{\mathrm{Cu}}{ }^{-1}$ )和文献中报道的结果. 结合高角度环形暗场扫描透射电子显微镜(HAADF-STEM)和X射线吸收精细结构 (XAFS) 技术, 对沉积沉淀法制备的催化剂进行表征, 发现在反应后铜物种的结构发生了明显的变化, 由小尺寸的氧化铜 $(\mathrm{CuO})$ 团簇转变为氧化亚铜 $\left(\mathrm{Cu}_{2} \mathrm{O}\right)$ 团簇, 并且铜物种的尺寸没有明显的增大. 为了进一步探索铜物种在预处理(氢气还原) 以及催化反应时(丙烯+氧气)的结构变化, 对不同方法合成的两种催化剂进行了原位X射线粉末衍射测试, 发现不同尺寸的

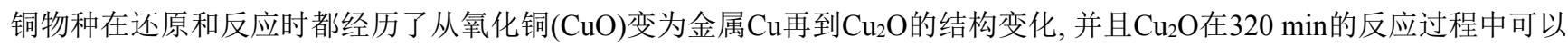
稳定存在, 说明它是该催化反应的活性物种. 另外, 通过原位双光束傅里叶变换红外光谱追踪反应时气体分子在催化剂表 面的吸脱附状态, 发现丙烯可以有效地吸附在小尺寸 $\mathrm{Cu} / \mathrm{SiO}_{2}$ 催化剂表面, 随着 $\mathrm{Cu}_{2} \mathrm{O}$ 的形成, 检测到了烯丙基中间体 $\left(\mathrm{CH}_{2}=\mathrm{CHCH}_{2}{ }^{*}\right)$ 的产生, 该物种可以与邻近 $\mathrm{Cu}_{2} \mathrm{O}$ 上的一个氧发生反应, 从而生成丙烯醛, 因此结合 $\mathrm{N}_{2} \mathrm{O}$ 滴定实验, 我们可认 为, 高度分散的小尺寸的 $\mathrm{Cu}_{2} \mathrm{O}$ 物种是丙烯进行高效选择性氧化反应生成丙烯醛的活性物种.

关键词: 丙烯选择性氧化; 氧化亚铜团簇; 形成丙烯醛; 活性物种; 原位表征

收稿日期: 2020-03-29. 接受日期: 2020-05-11. 出版日期: 2021-02-05.

*通讯联系人. 电话: (021)33932079; 电子信箱: sirui@sinap.ac.cn

\#通讯联系人. 电话: (0531)88363683; 电子信箱:jiacj@sdu.edu.cn

\$通讯联系人. 电话: (0411)84986162; 电子信箱: liujiaxu@dlut.edu.cn

通讯联系人.电话: (0731)88821727; 电子信箱:cma@hnu.edu.cn

基金来源：国家自然科学基金(21773288，21805167，21771117); 国家重点基础研究项目(2017YFA0403402); 国家自然科学基金 杰出青年科学家基金(21622106); 山东省杰出人才科学基金(JQ201703); 山东省博士基金(ZR2018BB010); 山东省泰山学者项目; 中央高校基本科研专项资金.

本文的电子版全文由Elsevier出版社在ScienceDirect上出版(http://www.sciencedirect.com/science/journal/18722067). 